\title{
Healthworker preparedness for COVID-19 management and implementation experiences: a mixed methods study in Uganda's refugee-hosting districts
}

Gloria Seruwagi ${ }^{1,2^{*}} \mathbb{C}$, Catherine Nakidde ${ }^{1}$, Felix Otieno ${ }^{1,3}$, Joshua Kayiwa ${ }^{4}$, Brian Luswata ${ }^{5}$, Eric Lugada ${ }^{1}$ Eric Awich Ochen ${ }^{1}$, Denis Muhangi ${ }^{1}$, Betty Okot ${ }^{1}$, Dunstan Ddamulira ${ }^{6}$, Andrew Masaba ${ }^{7}$ and Stephen Lawoko ${ }^{8}$

\begin{abstract}
Background: The negative impact of COVID-19 on population health outcomes raises critical questions on health system preparedness and resilience, especially in resource-limited settings. This study examined healthworker preparedness for COVID-19 management and implementation experiences in Uganda's refugee-hosting districts.

Methods: A cross sectional, mixed-method descriptive study in 17 health facilities in 7 districts from 4 major regions. Total sample size was 485 including $>370$ health care workers (HCWs). HCW knowledge, attitude and practices (KAP) was assessed by using a pre-validated questionnaire. The quantitative data was processed and analysed using SPSS 26 , and statistical significance assumed at $p<0.05$ for all statistical tests. Bloom's cutoff of $80 \%$ was used to determine threshold for sufficient knowledge level and practices with scores classified as high (80.0-100.0\%), average (60.079.0\%) and low ( $\leq 59.0 \%)$. HCW implementation experiences and key stakeholder opinions were further explored qualitatively using interviews which were audio-recorded, coded and thematically analysed.

Results: On average $71 \%$ of HCWs were knowledgeable on the various aspects of COVID-19, although there is a wide variation in knowledge. Awareness of symptoms ranked highest among $95 \%$ ( $p$ value $<0.0001$ ) of HCWs while awareness of the criteria for intubation for COVID-19 patients ranked lowest with only 35\% ( $p$ value $<0.0001$ ). Variations were noted on falsehoods about COVID-19 causes, prevention and treatment across Central ( $p$ value $<0.0356$ ) and West Nile $(p$ value $<0.0161)$ regions. Protective practices include adequate ventilation, virtual meetings and HCW training. Deficient practices were around psychosocial and lifestyle support, remote working and contingency plans for HCW safety. The work environment has immensely changed with increased demands on the amount of work, skills and variation in nature of work. HCWs reported moderate control over their work environment but with a high level of support from supervisors (88\%) and colleagues (93\%).
\end{abstract}

Conclusions: $\mathrm{HCW}$ s preparedness is inadequate in some aspects. Implementation of healthcare interventions is constrained by the complexity of Uganda's health system design, top-down approach of the national response

\footnotetext{
*Correspondence: gseruwagi@musph.ac.ug

${ }^{1}$ Centre for Health and Social Economic Improvement (CHASE-i) -

Department of Social Work and Social Administration (SWSA), Makerere

University, Kampala, Uganda

Full list of author information is available at the end of the article
}

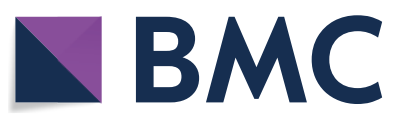

(c) The Author(s) 2021. Open Access This article is licensed under a Creative Commons Attribution 4.0 International License, which permits use, sharing, adaptation, distribution and reproduction in any medium or format, as long as you give appropriate credit to the original author(s) and the source, provide a link to the Creative Commons licence, and indicate if changes were made. The images or other third party material in this article are included in the article's Creative Commons licence, unless indicated otherwise in a credit line to the material. If material is not included in the article's Creative Commons licence and your intended use is not permitted by statutory regulation or exceeds the permitted use, you will need to obtain permission directly from the copyright holder. To view a copy of this licence, visit http://creativecommons.org/licenses/by/4.0/. The Creative Commons Public Domain Dedication waiver (http://creativeco mmons.org/publicdomain/zero/1.0/) applies to the data made available in this article, unless otherwise stated in a credit line to the data. 
to COVID-19 and longstanding health system bottlenecks. We recommend continuous information sharing on COVID-19, a design review with capacity strengthening at all health facility levels and investing in community-facing strategies.

Keywords: Health care workers (HCWs), Preparedness, Resilience, Health system, KAP, COVID-19

\section{Background}

Globally, armed conflict remains a key humanitarian crisis that has led to significant forced displacement in the twenty-first century, greatly impacting on host country health systems [1]. With the emergence of the COVID19 pandemic, significant challenges to health systems in general have been reported [2]. However, data on how the pandemic has impacted systems providing healthcare for refugee communities and the delivery of this care is scanty. This study scrutinizes the preparedness of health care workers (HCWs) for COVID-19 management in Uganda's diverse refugee settings.

\section{Refugee hosting in Uganda}

Uganda's open-door approach to hosting refugees has received international acclaim with its refugee policy described as the most progressive [3] and "the world's most compassionate refugee policy" [4]. The nation is among the world's top three refugee-hosting nations and largest in Africa, currently hosting approximately 1.5 million refugees and asylum seekers, mostly from South Sudan. While refugees are spread out in 12 districts, over $67 \%$ live in the West Nile region [5]. Uniquely, Uganda has no refugee camps; instead refugees live in gazetted settlements or wherever they may choose within wider society [6]. This is in line with the government's policy of service integration where refugees share all services with the host community [7]. Registered refugees have the freedom to freely move, be employed, engage in agriculture or business and access all services, including healthcare. While all refugee settlements in Uganda have lower-level health facilities, these facilities are also used by the local host communities integrated within or surrounding the settlements [8]. Health facilities in refugee settlements follow the national referral pathway which requires more complex cases from lower-level facilities to be managed at higher-level facilities [9]. How health systems have been affected by the COVID-19 pandemic has received some attention in the global literature [2]; however, the literature is scant on healthcare for refugee populations during this period.

\section{COVID-19 impact on health systems}

The COVID-19 pandemic has crippled all systems across the globe, some more than others. Even health systems in the more sophisticated and relatively high-performing countries like the United Kingdom, Spain, Italy and United States have been severely affected [10]. Almost all health systems have faced challenges with getting enough personal protective equipment (PPE) and other essential supplies, shortages in health care workers (HCWs) and overflowing hospitals due to the pandemic [2, 11, 12]. While all the pillars of the health system have been greatly affected, several studies have also reported disruptions in both the physical and psychosocial wellbeing of HCWs due to infection with COVID-19, burnout or other COVID-19 related occupational stressors [13-20] and compromised working conditions as some of the greatest challenges faced by the health workforce [21]. Furthermore, the evidence has indicated that satisfactory knowledge about COVID-19 among HCWs was associated with positive attitudes towards treating COVID-19 in Cyprus, South Africa, Sierra Leone, Ethiopia and Nigeria [22-26].

In Uganda, the national response to COVID-19 included a lockdown and other preventive measures like banning of public gatherings, institutional closures and movement restrictions including a ban on public transport and curfew. These were grounded in the country's previous efforts to curb outbreaks like Ebola and Marburg $[27,28]$. The Ministry of Health $(\mathrm{MOH})$ also instituted several guidelines for the continuity of essential health services and clinical management of COVID-19. This included screening, testing, isolation, institutional quarantine and setting up specific infection prevention and control (IPC) measures at health facility level. The World Health Organisation (WHO) played the critical role of developing guidance and training materials that could easily be adapted to local context by $\mathrm{MOH}$ and other COVID-19 responders [28]. However, several challenges continue to significantly undermine Uganda's health system preparedness to tackle the pandemic. These include the high HCW-patient ratios exacerbated by existing staffing gaps, porous borders which occasionally let through infected people including undocumented refugees from neighbouring countries, ineffective quarantine processes and low financing for the health system [28-30].

COVID-19 is a highly contagious infectious disease with higher likelihood for infection among HCWs compared to the general population [31]. The evidence from developed countries with high incidence of COVID-19 
shows that limitations in human and material capital can complicate its case management [32]. Additionally, the chronic shortages of PPEs alongside other IPC inputs have increased patient-to-staff transmissions with a heavy death toll on medical staff [33]. Consequently, these developments have caused concerns about the preparedness for COVID-19 management in struggling health systems. Moreover, previous research among HCWs has documented inadequate knowledge and distorted beliefs about causes, risk factors and treatments for different health conditions including cervical cancer [34], hypertension [35], diabetes [36] and mental illness [37]. It is therefore critical that HCWs have adequate knowledge about all aspects of COVID-19 from clinical manifestation, diagnosis, proposed treatment and prevention strategies [31].

While several studies have reported on health system preparedness including HCW knowledge, attitudes and practices (KAP) in sub-Saharan Africa and elsewhere in the world; to the best of our knowledge only one study [38] has reported on Ugandan HCWs. Even then, this study was conducted within four (4) university teaching hospitals, all located in the central region within approximately a 3-15 km radius from the National Referral Hospital (NRH) in Kampala, Uganda's capital city. Our research builds on and complements the critical knowledge generated by this study to assess HCW perceptions on their knowledge and practice. We report on HCW's perceived knowledge and implementation experiences with data collected in-person from a larger (>three-fold) sample size drawn from all levels of Uganda's health system and different geographical regions. We also show implications of the national health system design on health outcomes for forcibly displaced populations in the pandemic era.

\section{Methods}

\section{Study context: Uganda's health care system}

Uganda's health system comprises of both the private and public sector in terms of infrastructure, ownership and delivery of health services $[39,40]$. The health system is decentralized and hierarchical with seven levels starting from the household/village level and culminating at national referral institutions and the Ministry of Health [41]. In order of hierarchy there are the Village Health Teams (VHTs) or community health workers (CHWs) who are the first point of contact with health service users and resident within the village. Next is the Health Centre (HC) IIs, HCIIIs, HCIVs, District Hospitals, Regional Referral Hospitals (RRH) and National Referral Hospitals (NRH). In principle, each level of the health system is equipped to handle progressively complex cases while also referring to the next level upwards [9]. Referrals are therefore an integral part and key operational area of the success of the entire health system. The WHO lists the six key pillars or building blocks critical to any system's functionality as service delivery, the health workforce, health information systems, access to essential medicines or vaccines, financing, and leadership or governance [42]. Having a hierarchical system also means that, across each one of the building blocks, lower-level units in Uganda can only handle less-complex cases which also determines the considerably less resources and inputs available for their use.

Majority of the health facilities are public and therefore government/donor funded where, ideally, services should be provided free of charge. However, the latest figures report private expenditure as a percentage of Current Health Expenditure (CHE) to be $41 \%$ and out-of-pocket expenditure at $38 \%$ [43]. Health financing remains a key national challenge and the recommended Abuja target $15 \%$ of the GDP apportioned to health [40, 44, 45] has never been achieved, with average health sector allocations ranging from 6 to $9 \%[45,46]$. In particular, the low funding for Uganda's healthcare system continues to create an ongoing challenge of insufficient health workforce numbers [47] which has sometimes been mitigated by task shifting since 1918 [48] and which the evidence shows to have improved quality of care in the treatment of HIV/AIDS, tuberculosis, maternal, newborn and child health $(\mathrm{MNCH})$ programs as well as malaria [49-51]. However, task shifting has the potential to significantly undo its intended benefits in the absence of adequate training or supervision from skilled health workers, inappropriate compensation and work overloads as is the case for Uganda [52]. Older and more recent assessments show that Uganda continues to experience serious shortfalls and challenges across all six of the building blocks in its health system $[53,54]$.

\section{Study design}

This was a cross-sectional descriptive study using mixedmethods including a survey, key informant interviews (KII) and indepth interviews (IDI). The study's primary population were health care workers at facilities serving refugee populations in both urban and rural settlements located in the Central, South Western, West Nile and Northern regions of Uganda. Secondary participants included key informants from government ministries and local government offices involved in the refugee response, local leaders, NGOs and international agencies such as UNHCR. We collected data from seventeen (17) health facilities located within refugee settlements and outside hospitals which were direct referral points. 


\section{Sample size and sampling procedures}

The infectious nature of COVID-19 and how quickly it is spread implies that all categories of HCWs are at risk, ranging from the essential frontline workers to administrators, as they all share the same healthcare environment with the patients. Therefore the inclusion criteria was all workers at risk of contracting COVID-19 in the healthcare facility, but selected with Probability Proportional to Size (PPS), i.e. their numbers at the healthcare setting. The total sample size required for the quantitative arm of the study ( $370 \mathrm{HCWs}$ ) was determined using Kish's method for cross-sectional studies (formula 1 below) with the assumption that the proportion unprepared for COVID-19 management is previously unknown (i.e. in such cases, a proportion of $50 \%$ is usually assumed to ensure the largest possible sample, all other factors constant); a $95 \%$ confidence interval and a $5 \%$ margin of error. After the sample size of 370 was determined using Kish's formula we then apportioned each HCW cadre their number according to their fraction of representation at the health unit.

$$
n=z^{2} * p(1-p) / e^{2}
$$

where $\mathrm{n}$ is the optimal sample size, $\mathrm{Z}$ is the standard error of the confidence level (which is 1.96 if $95 \%$ confidence interval is applied), $\mathrm{p}$ is the proportion with the phenomena of interest (i.e. proportion prepared for COVID-19 management). We usually get this from previous studies. If no such previous study, take $\mathrm{p}=0.5$ as this guarantees the largest possible sample, all other factors constant, e is the margin of error, usually assumed between 1 and 5\% for conservative error.

For the qualitative arm of the study, 115 key informants with representation from key HCW cadre groups were purposively selected for interviews and focus groups discussions. The break-down of specific numbers within each cadre group are presented in Table 1.

\section{Measures}

\section{Dependent variables}

Knowledge, attitudes and practices (KAP) were assessed quantitatively using questionnaires capturing KAP in terms of causes, symptoms, risk factors, treatment and management of COVID-19. These were expressed in terms of statements with response alternatives on a Likert scale ranging between 1 and 4 i.e. "strongly disagree", "disagree", "agree", "strongly agree". Individual sums on each sub-scale (i.e. Knowledge, Attitude and Practice) were calculated, with higher scores representing higher KAP respectively. A modified Bloom's cutoff of $80 \%$ was used to determine threshold for sufficient knowledge level and practices on the various attributes measured
Table 1 Socio-demographic characteristics

\begin{tabular}{|c|c|c|}
\hline Characteristic & $\mathrm{n}$ & $\%$ \\
\hline \multicolumn{3}{|l|}{ District } \\
\hline Adjumani & 62 & 16.8 \\
\hline Gulu & 45 & 12.2 \\
\hline Kabarole & 55 & 14.9 \\
\hline Kampala & 130 & 35.1 \\
\hline Kyegegwa & 37 & 10.0 \\
\hline Mubende & 41 & 11.1 \\
\hline \multicolumn{3}{|l|}{ Region } \\
\hline Central & 171 & 46.2 \\
\hline West Nile & 69 & 18.7 \\
\hline Western & 92 & 24.9 \\
\hline Northern & 38 & 10.3 \\
\hline \multicolumn{3}{|l|}{ Health facility level } \\
\hline Region Referral hospital & 200 & 54.1 \\
\hline General hospital & 70 & 18.9 \\
\hline HCIV & 49 & 13.2 \\
\hline HC III & 26 & 7.0 \\
\hline $\mathrm{HC} \|$ & 9 & 2.4 \\
\hline Clinic & 9 & 2.4 \\
\hline \multicolumn{3}{|l|}{ Facility type } \\
\hline Public & 297 & 80.3 \\
\hline Private Not for Profit & 73 & 19.7 \\
\hline \multicolumn{3}{|l|}{ Gender } \\
\hline Male & 162 & 43.8 \\
\hline Female & 208 & 56.2 \\
\hline \multicolumn{3}{|l|}{ Education } \\
\hline Primary & 1 & 0.3 \\
\hline Secondary & 2 & 0.5 \\
\hline Certificate/ & 83 & 22.4 \\
\hline Diploma & 164 & 44.3 \\
\hline Vocational & 2 & 0.5 \\
\hline Bachelors' degree & 103 & 27.8 \\
\hline \multicolumn{3}{|l|}{ Marital status } \\
\hline Single & 109 & 29.5 \\
\hline Married & 241 & 65.1 \\
\hline Divorced/separated & 10 & 2.7 \\
\hline Widowed & 4 & 1.1 \\
\hline \multicolumn{3}{|l|}{ Religion } \\
\hline Catholic & 151 & 40.8 \\
\hline Protestant & 126 & 34.1 \\
\hline Muslim & 26 & 7.0 \\
\hline Pentecostal & 55 & 14.9 \\
\hline SDA & 12 & 3.2 \\
\hline \multicolumn{3}{|l|}{ Cadre } \\
\hline Consultant & 7 & 1.9 \\
\hline Medical officer & 28 & 7.6 \\
\hline Clinical officer & 38 & 10.3 \\
\hline Reg trained nurse & 89 & 24.1 \\
\hline Enrolled nurse & 87 & 23.5 \\
\hline
\end{tabular}


Table 1 (continued)

\begin{tabular}{llr}
\hline Characteristic & $\mathbf{n}$ & \% \\
\hline Pharmacist & 26 & 7.0 \\
Radiographer & 5 & 1.4 \\
Laboratory technologist & 32 & 8.6 \\
Other & 58 & 15.7 \\
Department & & \\
Emergency & 13 & 3.5 \\
Outpatient & 160 & 43.2 \\
Inpatient & 125 & 33.8 \\
Investigative dept & 12 & 3.2 \\
Other & 60 & \\
Age (Mean; SD) & $34.5(7.7)$ & \\
Number of Beds (Mean; SD) & $306(446)$ & \\
\hline
\end{tabular}

[55]. The statements are presented in Tables 3 and 5, and comparison of scores across different groups in Table 4 .

\section{Independent variables}

Demographic, and healthcare related characteristics of HCW were collected using survey instruments. These included gender, marital status, education level, cadre, facility, department among others.

Qualitatively, KAP was assessed using apriori developed interview guides. The survey was conducted using both Computer Assisted Personal Interviews (CAPI) while qualitative methods applied both virtual and inperson interviews.

\section{Analysis}

Qualitative interviews were audio-recorded, transcribed, coded and analysed thematically, aligning with study objectives. The quantitative data was processed and analyzed using SPSS 26, with statistical significance assumed at $p<0.05$ for all tests. Knowledge, attitude and practices were compared across regions, health facility levels, facility types, gender and levels of education using chi-square tests and $\mathrm{t}$-tests.

\section{Results}

\section{Sociodemographic characteristics}

A sample of health care workers $(n=370)$ were recruited from seventeen (17) health facilities serving refugees and host communities in seven (7) districts of Uganda. These health facilities are located in the Central, Western, Northern and North Western (West Nile) regions which also host refugees of different nationalities. Majority of the HCWs worked in regional referral and general hospitals, private facilities and held a diploma or certificate education in a medical field. There were slightly more women than men, and Catholics or Protestants were dominant. Participants varied in cadre, ranging from medical specialist to laboratory technologist; and were mainly placed in outpatient and inpatient settings. There was large variation in number of beds between the different health facilities owing to their variation in facility size; however, on average the facilities studied had 302 beds. The average age in the studied sample was 35 years, as shown in Table 1 below:

\section{Knowledge}

One of this study's objectives was to assess the selfreported knowledge, attitudes and practices (KAP) of healthcare workers in the pandemic era. Participants' overall KAP was analyzed using the sum score of each outcome and categorized Bloom's cut-off point [55].

Generally, there was a high level of knowledge among the HCWs on symptoms of COVID-19 (95\%), behavioral risk factors for COVID-19 transmission (93\%), that COVID-19 mortality is heightened if patient has other health conditions (92\%), which patient needs to be tested for COVID-19 (89\%), behavioral risk factors for COVID19 progression (88\%), what PPE to use in the fight against COVID-19 (86\%), demographic risk groups for COVID19 transmission (83\%), detailed clinical information about COVID-19 (82\%) and demographic risk groups for COVID-19 mortality (80\%).

We found average knowledge on myths about causes and prevention of COVID-19 (78\%), falsehoods about causes, prevention and treatment of COVID-19 (76\%), hospital's criteria for admission (75\%), terminology of the virus causing COVID-19 (74\%), myths about causes, prevention and treatment of COVID-19 (74\%), readiness to manage COVID-19 as a health worker (69\%), case definition of COVID-19 in use in Uganda (67\%), type of testing necessary for COVID-19 (66\%) and how to properly don or doff the full PPE for COVID-19 care (64\%).

There were low levels of knowledge on treatment options for COVID-19 (56\%), understanding of the pathophysiology of COVID-19 (55\%), how to administer appropriate levels of oxygen for COVID-19 patients (42\%), the recommendations around NIPPV and protective gear (38\%), criteria for intubation of COVID patients (35\%). The information is presented in Fig. 1 below.

There was no significant variation in knowledge levels across the 17 facilities in the surveyed regions. There was, however, a significantly high proportion ( $p$ value $=0.0356$ ) of $\mathrm{HCWs}$ with knowledge on falsehoods about causes, prevention and treatment of COVID-19 in Central compared to the other regions. There was also a higher proportion ( $p$ value $=0.0083$ ) of HCWs aware of knowledge on treatment options for COVID-19 in Central compared to the other regions. There was a significantly higher proportion $(p$ value $=0.0349)$ of HCWs 
I know the symptoms of COVID-19

I am aware there are behavioral risk factors for COVID-19 transmission

I am aware COVID-19 mortality is heightened if patient has other

I know which patient needs to be tested for COVID

I am aware there are behavioral risk factors for COVID-19 progression

I am sure of what PPE to use in the fight against COVID

I am aware that there are demographic risk groups for COVID-19 transmission

I feel confident that I know detailed clinical information about COVID-19

I am aware that there are demographic risk groups for COVID-19 mortality

I know there are some myths about causes and prevention of

I know there are some falsehoods about causes, prevention and treatment of COVID-19

I know our hospital's criteria for admission

I understand the terminology of the virus causing COVID-19

I know there are some myths about causes, prevention and treatment of COVID-19

I fell I am ready to manage COVID as a health care worker

I'm comfortable with the case definition of COVID in use in Uganda

I understand the type of testing necessary for COVID

I know how to properly don and doff the full PPE for COVID care

I am aware of the treatment options for COVID-19

I have a good understanding of the pathophysiology of COVID-19

I know well how to administer appropriate levels of oxygen for COVID patients

If I need to intubate a patient, I understand the recommendations around NIPPV and protective gear

I know the criteria for intubation of COVIDF patients

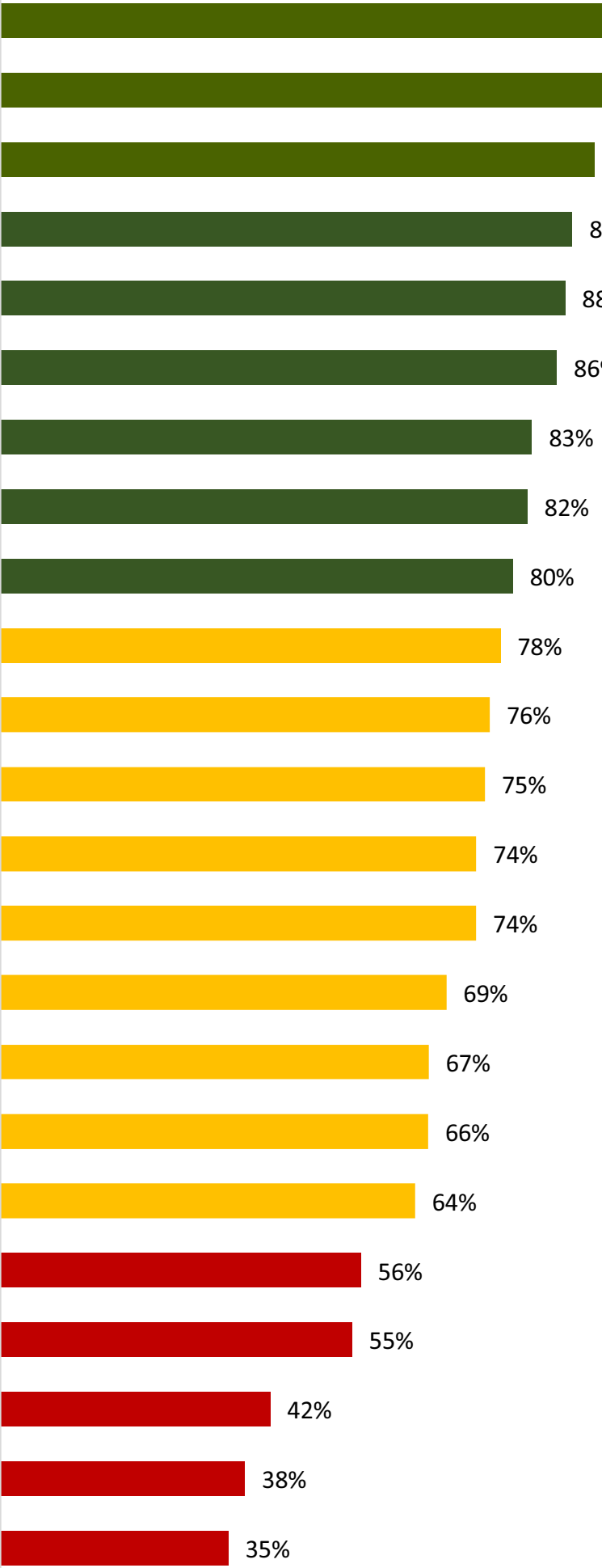

\section{$69 \%$}

$67 \%$

$66 \%$

$64 \%$

Fig. 1 Knowledge levels of health workers regarding the management of COVID-19 
Table 2 Variations in knowledge about COVID-19 among health workers by region

\begin{tabular}{|c|c|c|c|c|c|c|c|c|c|}
\hline & $\begin{array}{l}\text { Central } \\
(n=171) \\
(\%)\end{array}$ & $P$ value & $\begin{array}{l}\text { West Nile } \\
(\mathrm{n}=69) \\
(\%)\end{array}$ & Pvalue & $\begin{array}{l}\text { South } \\
\text { Western } \\
(n=35)(\%)\end{array}$ & $P$ value & $\begin{array}{l}\text { Northern } \\
(\mathrm{n}=95) \\
(\%)\end{array}$ & Pvalue & $\begin{array}{l}\text { Total } \\
(\mathrm{n}=370) \\
(\%)\end{array}$ \\
\hline I know the symptoms of COVID-19 & 93 & 0.1455 & 97 & 0.0084 & 97 & 0.6618 & 97 & 0.4066 & 95 \\
\hline $\begin{array}{l}\text { I am aware there are behavioral risk factors } \\
\text { for COVID-19 transmission }\end{array}$ & 93 & 0.3499 & 97 & 0.4742 & 94 & 0.6033 & 91 & 0.5072 & 93 \\
\hline $\begin{array}{l}\text { I am aware COVID-19 mortality is height- } \\
\text { ened if patient has other }\end{array}$ & 94 & 1.0000 & 94 & 0.2155 & 86 & 0.8262 & 90 & 0.5314 & 92 \\
\hline $\begin{array}{l}\text { I know which patient needs to be tested } \\
\text { for COVID }\end{array}$ & 86 & 0.4090 & 88 & 0.5702 & 91 & 0.2311 & 94 & 0.1474 & 89 \\
\hline $\begin{array}{l}\text { I am aware there are behavioral risk factors } \\
\text { for COVID-19 progression }\end{array}$ & 91 & 0.3189 & 87 & 0.8102 & 89 & 0.7200 & 83 & 0.1969 & 88 \\
\hline $\begin{array}{l}\text { I am sure of what PPE to use in the fight } \\
\text { against COVID }\end{array}$ & 84 & 0.3021 & 80 & 0.8170 & 97 & 0.8635 & 92 & 0.1185 & 86 \\
\hline $\begin{array}{l}\text { I am aware that there are demographic risk } \\
\text { groups for COVID-19 transmission }\end{array}$ & 86 & 0.5419 & 74 & 0.2031 & 80 & 0.0690 & 84 & 0.8163 & 83 \\
\hline $\begin{array}{l}\text { I feel confident that I know detailed clinical } \\
\text { information about COVID-19 }\end{array}$ & 87 & 0.3782 & 68 & 0.0791 & 85 & 0.6583 & 83 & 0.8204 & 82 \\
\hline $\begin{array}{l}\text { I am aware that there are demographic risk } \\
\text { groups for COVID-19 mortality }\end{array}$ & 83 & 0.4101 & 75 & 0.3514 & 77 & 0.6776 & 78 & 0.6665 & 80 \\
\hline $\begin{array}{l}\text { I know there are some myths about causes } \\
\text { and prevention of }\end{array}$ & 80 & 0.5988 & 78 & 1.0000 & 80 & 0.7874 & 72 & 0.2172 & 78 \\
\hline $\begin{array}{l}\text { I know there are some falsehoods about } \\
\text { causes, prevention and treatment of COVID- } \\
19\end{array}$ & 84 & $0.0356^{*}$ & 62 & $0.0161^{*}$ & 74 & 0.7947 & 72 & 0.4213 & 76 \\
\hline I know our hospital's criteria for admission & 68 & 0.0900 & 79 & 0.4811 & 77 & 0.7965 & 84 & 0.0639 & 75 \\
\hline $\begin{array}{l}\text { I understand the terminology of the virus } \\
\text { causing COVID-19 }\end{array}$ & 78 & 0.3175 & 67 & 0.2337 & 86 & 0.1226 & 67 & 0.1730 & 74 \\
\hline $\begin{array}{l}\text { I know there are some myths about causes, } \\
\text { prevention and treatment of COVID-19 }\end{array}$ & 78 & 0.3175 & 74 & 1.0000 & 63 & 0.1673 & 70 & 0.4329 & 74 \\
\hline $\begin{array}{l}\text { I fell I am ready to manage COVID as a } \\
\text { health care worker }\end{array}$ & 70 & 0.8152 & 58 & 0.0763 & 77 & 0.3323 & 74 & 0.3432 & 69 \\
\hline $\begin{array}{l}\text { I'm comfortable with the case definition of } \\
\text { COVID in use in Uganda }\end{array}$ & 70 & 0.4882 & 59 & 0.2024 & 83 & 0.0553 & 58 & 0.1009 & 67 \\
\hline $\begin{array}{l}\text { I understand the type of testing necessary } \\
\text { for COVID }\end{array}$ & 68 & 0.6475 & 68 & 0.7490 & 54 & 0.1612 & 67 & 0.8543 & 66 \\
\hline $\begin{array}{l}\text { I know how to properly don and doff the } \\
\text { full PPE for COVID care }\end{array}$ & 64 & 1.0000 & 57 & 0.2732 & 82 & $0.0349^{*}$ & 65 & 0.8562 & 64 \\
\hline $\begin{array}{l}\text { I am aware of the treatment options for } \\
\text { COVID-19 }\end{array}$ & 68 & $0.0083^{*}$ & 43 & $0.0486^{*}$ & 57 & 0.9106 & 43 & $0.0236^{*}$ & 56 \\
\hline $\begin{array}{l}\text { I have a good understanding of the patho- } \\
\text { physiology of COVID-19 }\end{array}$ & 62 & 0.1272 & 39 & 0.0154 & 71 & 0.0723 & 46 & 0.1172 & 55 \\
\hline $\begin{array}{l}\text { I know well how to administer appropriate } \\
\text { levels of oxygen for COVID patients }\end{array}$ & 47 & $0.0090^{*}$ & 35 & 0.2260 & 34 & 0.2648 & 44 & 0.1179 & 42 \\
\hline $\begin{array}{l}\text { If I need to intubate a patient, I understand } \\
\text { the recommendations around NIPPV and } \\
\text { protective gear }\end{array}$ & 41 & 0.2770 & 29 & 0.2816 & 49 & 0.3655 & 41 & 0.8602 & 38 \\
\hline $\begin{array}{l}\text { I know the criteria for intubation of COVIDF } \\
\text { patients }\end{array}$ & 39 & 0.5072 & 27 & 0.1577 & 34 & 0.2089 & 35 & 0.5902 & 35 \\
\hline
\end{tabular}

with knowledge on how to properly don and doff the full PPE for COVID care in South Western region compared to the other regions. The information is shown in Table 2 below:

Across health facilities, there was a significantly lower proportion of HCWs in general hospitals with awareness on detailed clinical information about COVID-19 ( $p$ value $=0.0077$ ), falsehoods about causes, prevention and treatment of COVID-19 ( $p$ value $=0.0092$ ), terminology of the virus causing COVID-19 ( $p$ value $=0.0406)$, readiness to manage COVID-19 ( $p$ value $=0.0095)$, treatment options for COVID-19 ( $p$ value $=0.0022)$, understanding 
Table 3 Variations in perceived knowledge about COVID-19 among HCWs by facility level

\begin{tabular}{|c|c|c|c|c|c|c|c|}
\hline & $\begin{array}{l}\text { Referral } \\
\text { Hospital } \\
\text { (\%) }\end{array}$ & $P$ value & $\begin{array}{l}\text { General } \\
\text { Hospital } \\
(\%)\end{array}$ & $P$ value & HC IV (\%) & $P$ value & Total (\%) \\
\hline I know the symptoms of COVID-19 & 96 & 0.5914 & 97 & 0.4684 & 90 & 0.1531 & 95 \\
\hline I am aware there are behavioral risk factors for COVID-19 transmission & 91 & 0.3966 & 94 & 0.7617 & 98 & 0.1801 & 93 \\
\hline $\begin{array}{l}\text { I am aware COVID-19 mortality is heightened if patient has other condi- } \\
\text { tions }\end{array}$ & 95 & 0.1824 & 91 & 0.7798 & 80 & $0.007^{*}$ & 92 \\
\hline I know which patient needs to be tested for COVID & 89 & 1.000 & 91 & 0.6201 & 84 & 0.3052 & 89 \\
\hline I am aware there are behavioral risk factors for COVID-19 progression & 88 & 1.000 & 84 & 0.3569 & 90 & 0.6836 & 88 \\
\hline I am sure of what PPE to use in the fight against COVID-19 & 86 & 1.000 & 80 & 0.1979 & 88 & 0.7031 & 86 \\
\hline $\begin{array}{l}\text { I am aware that there are demographic risk groups for COVID-19 trans- } \\
\text { mission }\end{array}$ & 84 & 0.762 & 77 & 0.2315 & 78 & 0.3886 & 83 \\
\hline I feel confident that I know detailed clinical information about COVID-19 & 87 & 0.126 & 68 & $0.0077^{*}$ & 78 & 0.4986 & 82 \\
\hline $\begin{array}{l}\text { I am aware that there are demographic risk groups for COVID-19 mortal- } \\
\text { ity }\end{array}$ & 81 & 0.776 & 76 & 0.4493 & 80 & 1.000 & 80 \\
\hline I know there are some myths about causes and prevention of COVID-19 & 78 & 1.000 & 73 & 0.3616 & 78 & 1.000 & 78 \\
\hline $\begin{array}{l}\text { I know there are some falsehoods about causes, prevention and treat- } \\
\text { ment of COVID-19 }\end{array}$ & 80 & 0.280 & 61 & $0.0092^{*}$ & 78 & 0.7577 & 76 \\
\hline I know our hospital's criteria for admission & 81 & 0.107 & 78 & 0.5935 & 63 & 0.0740 & 75 \\
\hline I understand the terminology of the virus causing COVID-19 & 76 & 0.603 & 62 & $0.0406^{*}$ & 69 & 0.4575 & 74 \\
\hline $\begin{array}{l}\text { I know there are some myths about causes, prevention and treatment } \\
\text { of COVID-19 }\end{array}$ & 76 & 0.603 & 70 & 0.4885 & 71 & 0.6549 & 74 \\
\hline I fell I am ready to manage COVID as a health care worker & 76 & 0.080 & 53 & $0.0095^{*}$ & 64 & 0.4801 & 69 \\
\hline I'm comfortable with the case definition of COVID in use in Uganda & 68 & 0.810 & 58 & 0.1471 & 65 & 0.7805 & 67 \\
\hline I understand the type of testing necessary for COVID & 68 & 0.632 & 64 & 0.7471 & 58 & 0.2707 & 66 \\
\hline I know how to properly don and doff the full PPE for COVID care & 63 & 0.814 & 53 & 0.0824 & 65 & 0.8911 & 64 \\
\hline I am aware of the treatment options for COVID-19 & 62 & 0.169 & 36 & $0.0022^{*}$ & 58 & 0.7913 & 56 \\
\hline I have a good understanding of the pathophysiology of COVID-19 & 57 & 0.649 & 40 & $0.0215^{*}$ & 59 & 0.5973 & 55 \\
\hline $\begin{array}{l}\text { I know well how to administer appropriate levels of oxygen for COVID } \\
\text { patients }\end{array}$ & 51 & $0.041^{*}$ & 31 & 0.0859 & 37 & 0.5052 & 42 \\
\hline $\begin{array}{l}\text { If I need to intubate a patient, I understand the recommendations } \\
\text { around NIPPV and protective gear }\end{array}$ & 43 & 0.248 & 30 & 0.2039 & 38 & 1.0000 & 38 \\
\hline I know the criteria for intubation of COVID-19 patients & 43 & 0.062 & 26 & 0.1445 & 25 & 0.1652 & 35 \\
\hline
\end{tabular}

of the pathophysiology of COVID-19, $(p$ value $=0.0215)$. Lower proportion ( $p$ value $=0.007$ ) of HCWs in HCIV were aware of COVID-19 mortality being heightened if a patient has other health conditions. Awareness on how to administer appropriate levels of oxygen for COVID patients was significantly higher $(p$ value $=0.041)$ in referral hospitals compared to other facility levels. This information is further shown in Table 3 below:

\section{Bivariate analyses on perceived knowledge and awareness} Geographical: HCWs ratings of their knowledge varied geographically. At district level, HCWs in Gulu and Kyegegwa rated their overall knowledge and case-management skills significantly higher than colleagues in other districts. With regard to facility variations, healthworkers at HC III and Regional Referral hospitals rated their overall knowledge and case management-related skills significantly higher than $\mathrm{HCW}$ at other levels on average. In terms of department or position variations, consultants and medical officers demonstrated knowledge in all regards higher than other staff cadre groups on average. There was no significant variation in knowledge by department or gender. However, there was a significantly higher proportion $(p$ value $=0.0239)$ of male HCWs who understood the terminology of the virus causing COVID-19 compared to female HCWs. Compared across levels of education, HCWs who had attained atleast a Bachelor's degree were significantly knowledgeable on detailed clinical information about COVID-19 ( $p$ value $=0.0066)$, terminology of the virus causing COVID-19 ( $p$ value $=0.0028)$, treatment options for COVID-19 ( $p$ value $=0.0062$ ), understanding of the pathophysiology of COVID-19 ( $p$ value $=0.0010)$ as compared to HCWs with other qualifications. HCWs with certificate level education reported significantly 
Table 4 Variations in HCWs knowledge and awareness by socio-demographic and facility factors

\begin{tabular}{|c|c|c|c|}
\hline Characteristic & $\begin{array}{l}\text { Overall knowledge (24-96) } \\
\text { Mean (SD) }\end{array}$ & $\begin{array}{l}\text { Knowledge of relevance to case management } \\
\text { (15-60) Mean (SD) }\end{array}$ & $\begin{array}{l}\text { Knowledge of relevance to } \\
\text { prevention (9-36) Mean (SD) }\end{array}$ \\
\hline \multicolumn{4}{|l|}{ District } \\
\hline Adjumani & $65.8(12.5)^{*}$ & $38.9(8.8)^{*}$ & $26.9(5.0)$ \\
\hline Gulu & $70.1(12.9)$ & $42.4(8.9)$ & $27.7(5.1)$ \\
\hline Kabarole & $65.1(10.9)$ & $38.8(6.9)$ & $26.3(5.1)$ \\
\hline Kampala & $68.7(9.55)$ & $40.8(6.9)$ & $27.9(3.9)$ \\
\hline Kyegegwa & $70.3(12.3)$ & $43.2(8.0)$ & $27.1(5.0)$ \\
\hline Mubende & $68.1(12.3)$ & $40.5(9.0)$ & $27.6(4.3)$ \\
\hline \multicolumn{4}{|l|}{ Health facility level } \\
\hline Region Referral hospital & $68.7(11.2)^{*}$ & $41.2(7.9)^{*}$ & $27.5(4.5)$ \\
\hline General hospital & $65.1(12.0)$ & $38.3(8.6)$ & $26.7(4.6)$ \\
\hline HCIV & $67.5(12.0)$ & $40.3(8.3)$ & $27.2(4.9)$ \\
\hline HC III & $73.0(10.6)$ & $44.6(6.1)$ & $28.4(5.4)$ \\
\hline $\mathrm{HC} \|$ & $60.6(8.3)$ & $36.1(6.4)$ & $24.4(2.5)$ \\
\hline Clinic & $66.2(6.2)$ & $38.4(3.2)$ & $27.8(3.9)$ \\
\hline \multicolumn{4}{|l|}{ Gender } \\
\hline Male & $69.4(11.0)^{*}$ & $41.5(7.7)^{*}$ & $27.9(4.6)^{*}$ \\
\hline Female & $66.7(11.6)$ & $39.8(8.1)$ & $26.6(4.5)$ \\
\hline \multicolumn{4}{|l|}{ Education } \\
\hline Certificate & $63.6(11.7)^{*}$ & $37.8(8.5)^{*}$ & $26.6(4.2)^{*}$ \\
\hline Diploma & $67.2(10.7)$ & $40.2(7.5)$ & $26.9(4.5)$ \\
\hline Bachelors'degree & $71.8(10.9)$ & $42.8(7.5)$ & $28.6(4.7)$ \\
\hline \multicolumn{4}{|l|}{ Marital status } \\
\hline Single & $68.8(10.9)$ & $41.0(7.4)$ & $27.8(4.5)$ \\
\hline Married & $67.4(11.5)$ & $40.4(8.1)$ & $27.0(4.6)$ \\
\hline Divorced/separated & $69.7(7.9)$ & $40.9(6.7)$ & $28.8(2.3)$ \\
\hline Widowed & $74.0(24.1)$ & $44.3(17.3)$ & $29.8(7.3)$ \\
\hline \multicolumn{4}{|l|}{ Religion } \\
\hline Catholic & $67.9(11.1)$ & $40.6(7.9)$ & $27.3(4.5)$ \\
\hline Protestant & $66.9(11.6)$ & $40.0(7.9)$ & $26.9(4.6)$ \\
\hline Muslim & 70.5 (11.6) & $42.8(8.4)$ & $27.7(4.2)$ \\
\hline Pentecostal & $69.7(11.7)$ & $41.0(7.8)$ & $28.7(4.8)$ \\
\hline SDA & $66.1(11.3)$ & $39.8(8.8)$ & $26.3(4.6)$ \\
\hline \multicolumn{4}{|l|}{ Cadre } \\
\hline Consultant & $80.0(7.8)^{*}$ & $49.4(3.7)^{*}$ & $30.6(4.3)^{*}$ \\
\hline Medical officer & $75.7(9.4)$ & $45.6(6.2)$ & $30.1(5.2)$ \\
\hline Clinical officer & $68.2(9.0)$ & $41.4(6.3)$ & $26.8(4.5)$ \\
\hline Reg trained nurse & $68.2(12.4)$ & $41.0(8.5)$ & $27.2(5.0)$ \\
\hline Enrolled nurse & $64.7(12.2)$ & $38.1(9.1)$ & $26.6(4.0)$ \\
\hline Pharmacist & $66.6(8.8)$ & $39.1(6.3)$ & $27.5(3.4)$ \\
\hline Radiographer & $66.8(5.0)$ & $40.6(4.7)$ & $26.2(1.1)$ \\
\hline Laboratory technologist & $70.1(9.8)$ & $41.9(6.3)$ & $28.2(4.4)$ \\
\hline Other & $66.5(10.9)$ & $39.7(7.2)$ & $26.8(4.9)$ \\
\hline \multicolumn{4}{|l|}{ Department } \\
\hline Emergency & $70.5(10.3)$ & $42.8(7.5)$ & $27.7(4.7)$ \\
\hline Outpatient & $67.6(10.1)$ & $40.4(7.1)$ & $27.2(4.5)$ \\
\hline Inpatient & $67.6(13.1)$ & $40.1(9.3)$ & $27.5(4.8)$ \\
\hline Investigative dept & $69.4(7.9)$ & $42.1(5.2)$ & $27.3(4.1)$ \\
\hline Other & $68.8(11.8)$ & $41.5(7.7)$ & $27.3(4.8)$ \\
\hline
\end{tabular}

*Statistically significant at $p<0.05$ 
Table 5 Variations in HCW knowledge by health facility type

\begin{tabular}{|c|c|c|c|c|c|}
\hline & $\begin{array}{l}\text { Public } \\
(n=297) \\
(\%)\end{array}$ & $P$ value & $\begin{array}{l}\text { Private Not for } \\
\text { Profit }(n=73) \\
\text { (\%) }\end{array}$ & $P$ value & $\begin{array}{l}\text { Total } \\
(n=370) \\
(\%)\end{array}$ \\
\hline I know the symptoms of COVID-19 & 95 & 1.0000 & 96 & 0.7162 & 95 \\
\hline I am aware there are behavioral risk factors for COVID-19 transmission & 93 & 1.0000 & 94 & 0.7573 & 93 \\
\hline I am aware COVID-19 mortality is heightened if patient has other & 92 & 1.0000 & 96 & 0.2316 & 92 \\
\hline I know which patient needs to be tested for COVID & 87 & 0.4281 & 96 & 0.0669 & 89 \\
\hline I am aware there are behavioral risk factors for COVID-19 progression & 87 & 0.6976 & 90 & 0.6271 & 88 \\
\hline I am sure of what PPE to use in the fight against COVID & 85 & 0.7152 & 94 & $0.0469^{*}$ & 86 \\
\hline I am aware that there are demographic risk groups for COVID-19 transmission & 81 & 0.5033 & 89 & 0.2019 & 83 \\
\hline I feel confident that I know detailed clinical information about COVID-19 & 81 & 0.7409 & 86 & 0.4099 & 82 \\
\hline I am aware that there are demographic risk groups for COVID-19 mortality & 78 & 0.5280 & 88 & 0.1094 & 80 \\
\hline I know there are some myths about causes and prevention & 78 & 1.0000 & 75 & 0.5752 & 78 \\
\hline I know there are some falsehoods about causes, prevention and treatment of COVID-19 & 76 & 1.0000 & 75 & 0.8554 & 76 \\
\hline I know our hospital's criteria for admission & 75 & 1.0000 & 77 & 0.7175 & 75 \\
\hline I understand the terminology of the virus causing COVID-19 & 72 & 0.5629 & 81 & 0.2064 & 74 \\
\hline I know there are some myths about causes, prevention and treatment of COVID-19 & 73 & 0.7712 & 76 & 0.7210 & 74 \\
\hline I fell I am ready to manage COVID as a health care worker & 67 & 0.5820 & 79 & 0.0868 & 69 \\
\hline I'm comfortable with the case definition of COVID in use in Uganda & 69 & 0.6280 & 57 & 0.1012 & 67 \\
\hline I understand the type of testing necessary for COVID & 65 & 0.8115 & 72 & 0.3197 & 66 \\
\hline I know how to properly don and doff the full PPE for COVID care & 61 & 0.4816 & 79 & $0.0132^{*}$ & 64 \\
\hline I am aware of the treatment options for COVID-19 & 57 & 0.8193 & 53 & 0.6378 & 56 \\
\hline I have a good understanding of the pathophysiology of COVID-19 & 55 & 1.0000 & 54 & 0.8755 & 55 \\
\hline I know well how to administer appropriate levels of oxygen for COVID patients & 42 & 1.0000 & 41 & 0.8744 & 42 \\
\hline $\begin{array}{l}\text { If I need to intubate a patient, I understand the recommendations around NIPPV and } \\
\text { protective gear }\end{array}$ & 40 & 0.6418 & 30 & 0.1954 & 38 \\
\hline I know the criteria for intubation of COVID patients & 38 & 0.4791 & 26 & 0.1370 & 35 \\
\hline
\end{tabular}

lower knowledge on understanding the terminology of the virus causing COVID-19 ( $p$ value $=0.0002$ ), understanding the type of testing necessary for COVID-19 ( $p$ value $=0.0038)$, treatment options for COVID-19 $(p$ value $=0.0051)$, pathophysiology of COVID-19 ( $p$ value $=0.0010$ ), how to administer appropriate levels of oxygen for COVID-19 patients ( $p$ value $=0.0438$ ). There was no significant variation in knowledge by age, marital status and religion of HCWs (Table 4).

There was no significant variation in levels of knowledge across public and private health facilities. There was, however, a significantly higher proportion (0.0469) of HCWs in private facilities with knowledge on what PPE to use in the fight against COVID-19 compared to health workers in public facilities. Knowledge on how to properly don and doff the full PPE for COVID-19 care was significantly higher ( $p$ value $=0.0132$ ) in private facilities compared to public facilities (Table 5).

Data from the qualitative arm of the study provides some insight and triangulation for quantitative results. First, there was a general understanding of COVID-19 among HCWs, particularly on its signs and symptoms. In some geographical areas training and strengthening the capacity of HCWs for case management had been conducted, particularly by health implementing partner agencies in refugee settlements:

We have a team comprising of healthworkers who have been trained on COVID-19 case management... these healthworkers have been subjected to various, about three, simulations for COVID-19 case management. So during simulation exercises we bring in real life scenarios of an actual case of COVID-19 just to build their capacity, and make sure that they are ready to respond incase we get a confirmed case in the settlement here... and then it is mandatory for all the healthworkers to have basic knowledge. So I would say all of them have been trained, but some have been given further guidance with simulation exercises (Implementing Partner, Settlement \#1, Region 2)

The moment we heard that its COVID our bosses immediately arranged trainings for us and also equipped us with the essential supplies like more PPEs to go along with that knowledge. Atleast now we know something although we are continuing to 
learn about this strange disease. Also, the Ministry of Health guidelines are helping us all [HCW 1, Private Health Facility, Region 3]

However, findings in some public facilities showed that COVID-specific training had not yet taken place, although some information had been shared to increase HCW knowledge and awareness:

Up to now we have not seen anyone from the district or Ministry [of Health] coming to train us on COVID. Maybe they will come with time... we received some of these posters on the disease and are using that information and our training to try and protect ourselves and our clients...we are improvising but it's tough (HCW 2, Public Health Facility, Region 2)

This was confirmed by data from the national level which also explained the government's targeted and phased approach to strengthening health facility capacity and preparedness. The focus was particularly at referral points where most COVID-19 cases were going to end up, as opposed to spreading thin by attempting to simultaneously equip all health facilities at different levels:

Part of the reason we locked down was to prepare care capacity and in preparing care capacity, we made sure that every district hospital has a COVID19 care capacity... and a specialized COVID-19 team. We have moved around and trained, we made sure that regional referral hospitals have capacity... The model is such that the very severe cases of COVID-19 are supposed to be managed at the regional referrals [hospitals]. The district hospitals are supposed to manage the minor cases; and in this case because we have few cases and all the cases go to the regional referral, we have not covered all the hospitals yet. We have not gotten there yet but will get there. Because COVID-19 one day it's going to become like malaria and the patients will go to any healthcare centre and be treated...But for now we make sure that the plan is expanded very well and it will come to reach to the point where we are going slowly (KII, Policymaker)

In agreement with some of the quantitative findings on training HCWs and resulting knowledge, implementing partners and other stakeholders reported constraints with training materials and content, particularly in the early phase of COVID-19. They also highlighted the limitations that short training intervals have on the extent to which they can strengthen $\mathrm{HCW}$ capacity:

All healthworkers in the settlement have been trained even though it is, I don't know, maybe a one day's training because the material on COVID is really not so much... and you have seen the trends, it is specifically the asymptomatic or mild cases so if a severe case happened I don't think our healthworkers here can handle. They will immediately refer (National-Settlement stakeholder 1)

Inspite of this training, there were some knowledge and skill gaps across most facilities, more especially at the lower-level health facilities:

I won't lie to you, most of us here know something about this COVID but not everything. It is a new disease and we are also just learning, just like everyone else. Ofcourse we may know abit more than the community but until we have proper training, we will just have to rely on our usual skills, the SOPs and the information as it keeps reaching us (HCW 3 , Public Health Facility, Region 1)

We keep having our knowledge added on to slowly slowly but generally most healthworkers, myself included, do not feel very confident to handle a COVID case right now. So for me I suspect we shall refer [to COVID management centres] if we get one and have not been given extra training by that time (HCW 4, Public Health Facility, Region 3)

\section{Practices}

\section{Health care worker and facility practices regarding COVID-19}

Study results show healthworker and facility practices regarding COVID-19 to be less than optimal in several regards. Between 5 and 30\% strongly disagreed/disagreed that practices to ensure patient safety from transmission (e.g. disinfection, social distancing and ventilation) are adhered to or in place. Between 11 and 55\% strongly disagreed/disagreed that practices and precautions to ensure staff safety (e.g. mapping out risk and hazards, staff safety and health contingency plans, non-critical staff working at home or shift working) were being adhered to. Over 30\% strongly disagreed/disagreed that practices to improve communication (e.g. having a person assigned for the purpose) were in existence at their facility. Table 6 illustrates this further:

Using Bloom's cut-off points, there were high-level practices among HCWs on placing patients in adequately ventilated rooms (94\%), respiratory, hand hygiene and prevention of healthcare-associated infections (92\%); avoiding face-to-face meetings and giving preference to phone calls, email or virtual meetings (92\%); improved ventilation around workspaces (89\%) and training of facility management, workers or their representatives on management of COVID at the facility (88\%).Workers 
Table 6 COVID-19 practices

\begin{tabular}{|c|c|c|c|c|c|c|c|c|}
\hline \multirow[t]{2}{*}{ HCW/facility practices } & \multicolumn{2}{|c|}{$\begin{array}{l}\text { Strongly } \\
\text { disagree }\end{array}$} & \multicolumn{2}{|c|}{ Disagree } & \multicolumn{2}{|c|}{ Agree } & \multicolumn{2}{|c|}{$\begin{array}{l}\text { Strongly } \\
\text { agree }\end{array}$} \\
\hline & $\mathrm{n}$ & $\%$ & $\mathbf{n}$ & $\%$ & $\mathbf{n}$ & $\%$ & $\mathbf{n}$ & $\%$ \\
\hline Patients, visitors aware of COVID-19 prevention practices & 23 & 6.2 & 81 & 21.9 & 194 & 52.4 & 69 & 18.7 \\
\hline HCWs aware of COVID-19 prevention practices & 5 & 1.4 & 24 & 6.5 & 188 & 50.8 & 150 & 40.5 \\
\hline HCWs apply standard precautions for all patients & 18 & 4.9 & 89 & 24.1 & 173 & 46.8 & 83 & 22.4 \\
\hline Droplets and contact precautions recommended for febrile, coughing patients & 22 & 5.9 & 57 & 15.4 & 181 & 48.9 & 102 & 27.6 \\
\hline Patients should be placed in adequately ventilated rooms & 3 & 0.8 & 20 & 5.4 & 164 & 44.3 & 174 & 47.0 \\
\hline One-meter distance between beds ensured for all patients & 35 & 9.5 & 65 & 17.6 & 154 & 41.6 & 111 & 30.0 \\
\hline Hospital has an active COVID-19 taskforce & 16 & 4.3 & 47 & 12.7 & 155 & 41.9 & 141 & 38.1 \\
\hline Hospital has written COVID-19 preparedness plans & 36 & 9.7 & 95 & 25.7 & 146 & 39.5 & 87 & 23.5 \\
\hline People are assigned to communicate status and impact of COVID-19 to staff & 40 & 10.8 & 79 & 21.4 & 165 & 44.6 & 85 & 23.0 \\
\hline People are assigned to communicate status and impact of COVID-19 with authorities & 37 & 10.0 & 88 & 23.8 & 160 & 43.2 & 82 & 22.2 \\
\hline People are assigned to communicate with patients about COVID-19 & 29 & 7.8 & 101 & 27.3 & 172 & 46.5 & 67 & 18.1 \\
\hline Facility has mapped the COVID-19 risks/hazards for all work points & 26 & 7.0 & 117 & 31.6 & 165 & 44.6 & 59 & 15.9 \\
\hline Staff safety is included in contingency plans & 48 & 13.0 & 100 & 27.0 & 168 & 45.4 & 51 & 13.8 \\
\hline Non-critical staff asked to work from home & 103 & 27.8 & 101 & 27.3 & 112 & 30.3 & 52 & 14.1 \\
\hline Shifts introduced to avoid HCW concentrations & 82 & 22.2 & 93 & 25.1 & 125 & 33.8 & 69 & 18.7 \\
\hline Facility has a COVID-19 M\&E mechanism & 51 & 13.8 & 76 & 20.5 & 179 & 48.4 & 63 & 17.0 \\
\hline Facility trained management, workers on COVID-19 management & 25 & 6.8 & 46 & 12.4 & 185 & 50.0 & 111 & 30.0 \\
\hline Staff assisted to minimize direct contact with customers, ensure personal hygiene & 16 & 4.3 & 29 & 7.8 & 190 & 51.4 & 134 & 36.2 \\
\hline Workers in direct contact with clients have PPEs & 27 & 7.3 & 48 & 13.0 & 182 & 49.2 & 111 & 30.0 \\
\hline Risk of COVID-19 in travel has been assessed & 48 & 13.0 & 70 & 18.9 & 179 & 48.4 & 69 & 18.7 \\
\hline Facility maintains regular communication with workers & 50 & 13.5 & 76 & 20.5 & 166 & 44.9 & 76 & 20.5 \\
\hline HCWs assisted to manage any emerging psychosocial risks & 44 & 11.9 & 86 & 23.2 & 179 & 48.4 & 59 & 15.9 \\
\hline Virtual meetings preferred to Face-to-face meetings & 59 & 15.9 & 102 & 27.6 & 132 & 35.7 & 72 & 19.5 \\
\hline Hand washing and/or sanitization culture promoted & 9 & 2.4 & 19 & 5.1 & 151 & 40.8 & 188 & 50.8 \\
\hline Surfaces regularly wiped with disinfectants & 16 & 4.3 & 60 & 16.2 & 161 & 43.5 & 131 & 35.4 \\
\hline Workspace ventilation is improved & 28 & 7.6 & 86 & 23.2 & 166 & 44.9 & 87 & 23.5 \\
\hline Good respiratory hygiene promoted and communicated & 7 & 1.9 & 33 & 8.9 & 167 & 45.1 & 161 & 43.5 \\
\hline Social distancing is promoted in congregate settings & 27 & 7.3 & 58 & 15.7 & 157 & 42.4 & 127 & 34.3 \\
\hline HCWs suspected COVID-19 encouraged to self-isolate & 22 & 5.9 & 62 & 16.8 & 148 & 40.0 & 135 & 36.5 \\
\hline HCWs informed what to do when they suspect to have COVID-19 & 13 & 3.5 & 41 & 11.1 & 182 & 49.2 & 131 & 35.4 \\
\hline Facility has planned disinfecting areas & 14 & 3.8 & 43 & 11.6 & 177 & 47.8 & 133 & 35.9 \\
\hline
\end{tabular}

with suspected symptoms of COVID-19 were encouraged not to come to the workplace and follow available guidance (85\%). Additionally, staff were informed on what to do when they suspect to have COVID-19 (84\%). The health facilities had an active taskforce to manage COVID-19 (82\%); the facility had a monitoring and evaluation mechanism of the COVID-19 prevention strategies and plans (81\%). Staff had been assisted to minimize the direct contact with customers and ensure personal hygiene practices such as hand washing and use of hand sanitizers (80\%).

There were average-level practices on hand washing at the facility (79\%). Droplets and contact precautions were recommended for febrile and coughing patients (78\%), social distancing was being promoted in congregate settings where clients gather (77\%), good respiratory (e.g. face mask) hygiene was promoted and communicated (77\%) and the one- meter distance between beds ensured regardless of whether patients are suspected of having COVID-19 (73\%). Patients and visitors were aware of respiratory and hand hygiene and prevention of healthcareassociated infections (72\%); while HCWs were applying standard precautions for all patients (71\%). Surfaces (e.g. desks and workstations, doorknobs, telephones keyboards and working objects) were regularly wiped with disinfectant (69\%). HCWs who came in direct contact with clients had been provided with personal protective equipment (68\%); health facility had written COVID-19 
Patients should be placed in adequately ventilated rooms

Face-to-face meetings have been avoided, giving preference to phone calls, email or virtual meetings

Health care workers are aware of respiratory and hand hygiene and prevention of healthcare-associated infections

Ventilation around workspaces have been improved

Facility has trained management, workers and their representatives on management of COVID at the facility

Workers with suspected symptoms of COVID-19 are encouraged not to come to the workplace and to follow the guidance of the local...

Staff are informed on what to do when they suspect to have COVID

Hospital has an active taskforce to manage COVID

The facility has a monitoring and evaluation mechanism of the COVID prevention strategies and plans.

Staff has been assisted to minimize the direct contact with customers and ensure personal hygiene practices such as hand washing and..

A culture of hand washing and/or sanitization is promoted at the facility

Droplets and contact precautions are recommended for febrile and coughing patients

Social distancing is promoted in congregate settings where clients gather

Good respiratory (e.g. face mask) hygiene is promoted and communicated

One- meter distance between beds is ensured regardless of whether patients are suspected of having COVID-19

Patients, and visitors are aware of respiratory and hand hygiene and prevention of healthcare-associated infections

$\mathrm{HCW}$ are applying standard precautions for all patients

Surfaces (e.g. Desks and workstations, doorknobs, telephones keyboards and working objects) are regularly wiped with disinfectant Workers who come in direct contact with clients have been provided with personal protective equipment

Hospital has written COVID-19 preparedness plans and accessible to all staff

A person has been assigned responsibility for communications with staff, regarding the status and impact of COVID-19

Risk of COVID in travel has been assessed. Non essential travel has been avoided.

Shifts have been introduced to avoid large concentrations of workers in the facilities

A person has been assigned responsibility for communications with health authorities regarding the status and impact of COVID-19 Facility maintains regular communication with workers and workers' representatives, including over the internet, or when not possible,...

A person has been assigned responsibility for communications with patients, and their families regarding COVID-19

The facility has mapped the COVID risks/hazards of all workpoints and covering all jobs
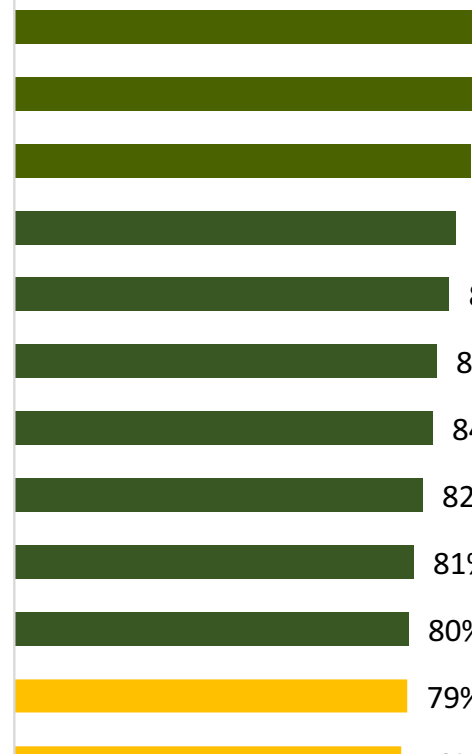

$80 \%$

$79 \%$

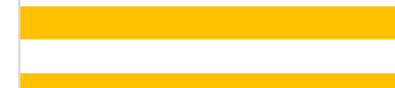

$78 \%$

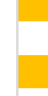

$77 \%$

$77 \%$

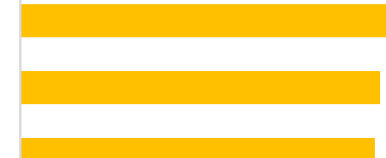

$73 \%$

$72 \%$

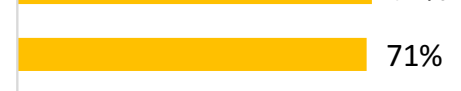

$71 \%$

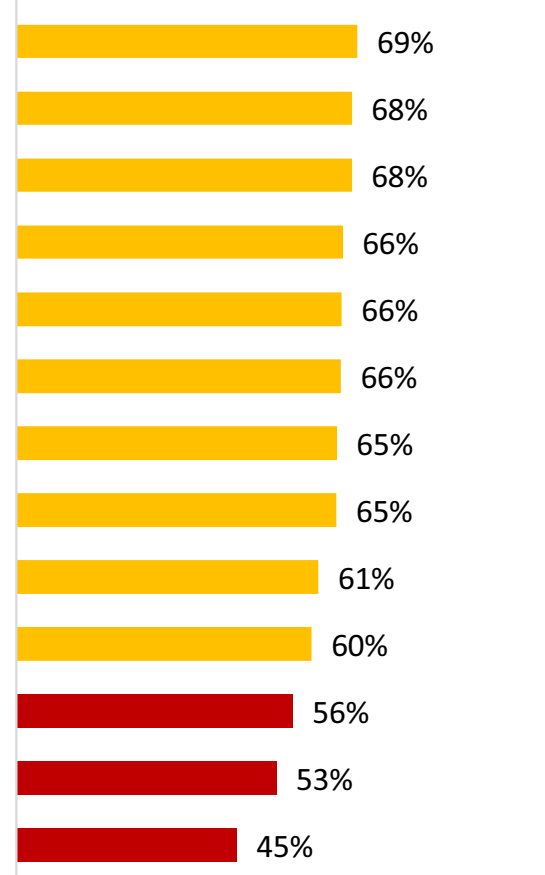

Workers are assisted to manage any emerging psychosocial risks, new forms of work arrangements, and in the promotion and... Non critical staff have been asked to work from home or to stay at home

Fig. 2 COVID-19 related practices among HCWs 
Table 7 Variations in health worker practices by region represented

\begin{tabular}{|c|c|c|c|c|c|c|c|c|c|}
\hline & $\begin{array}{l}\text { Central } \\
(\mathrm{n}=171) \\
(\%)\end{array}$ & $P$ value & $\begin{array}{l}\text { West Nile } \\
(n=69) \\
(\%)\end{array}$ & $P$ value & $\begin{array}{l}\text { South } \\
\text { Western } \\
(n=35)(\%)\end{array}$ & $P$ value & $\begin{array}{l}\text { Northern } \\
(\mathrm{n}=95) \\
(\%)\end{array}$ & $P$ value & $\begin{array}{l}\text { Total } \\
(\mathrm{n}=370) \\
(\%)\end{array}$ \\
\hline $\begin{array}{l}\text { Patients should be placed in adequately } \\
\text { ventilated rooms }\end{array}$ & 90 & 0.0959 & 97 & 0.3173 & 97 & 0.4664 & 97 & 0.2485 & 94 \\
\hline $\begin{array}{l}\text { Face-to-face meetings have been avoided, } \\
\text { giving preference to phone calls, email or } \\
\text { virtual meetings }\end{array}$ & 90 & 0.4416 & 91 & 0.7808 & 97 & 0.2857 & 96 & 0.1785 & 92 \\
\hline $\begin{array}{l}\text { Health care workers are aware of respira- } \\
\text { tory and hand hygiene and prevention of } \\
\text { healthcare-associated infections }\end{array}$ & 88 & 0.1361 & 96 & 0.2436 & 97 & 0.2857 & 95 & 0.3192 & 92 \\
\hline $\begin{array}{l}\text { Ventilation around workspaces have been } \\
\text { improved }\end{array}$ & 85 & 0.1877 & 96 & 0.0742 & 94 & 0.3583 & 89 & 1.0000 & 89 \\
\hline $\begin{array}{l}\text { Facility has trained management, workers } \\
\text { and their representatives on management } \\
\text { of COVID at the facility }\end{array}$ & 82 & 0.0609 & 91 & 0.4743 & 94 & 0.2878 & 94 & 0.0928 & 88 \\
\hline $\begin{array}{l}\text { Workers with suspected symptoms of } \\
\text { COVID-19 are encouraged not to come to } \\
\text { the workplace and to follow the guidance } \\
\text { of the local authorities }\end{array}$ & 87 & 0.5379 & 87 & 0.6669 & 91 & 0.3356 & 78 & 0.1009 & 85 \\
\hline $\begin{array}{l}\text { Staff are informed on what to do when they } \\
\text { suspect to have COVID }\end{array}$ & 86 & 0.5491 & 77 & 0.1567 & 89 & 0.4360 & 86 & 0.6321 & 84 \\
\hline $\begin{array}{l}\text { Hospital has an active taskforce to manage } \\
\text { COVID }\end{array}$ & 83 & 0.777 & 74 & 0.1223 & 74 & 0.2465 & 91 & 0.0337 & 82 \\
\hline $\begin{array}{l}\text { The facility has a monitoring and evaluation } \\
\text { mechanism of the COVID prevention strate- } \\
\text { gies and plans }\end{array}$ & 74 & 0.0643 & 84 & 0.5564 & 91 & 0.1427 & 87 & 0.1729 & 81 \\
\hline $\begin{array}{l}\text { Staff has been assisted to minimize the } \\
\text { direct contact with customers and ensure } \\
\text { personal hygiene practices such as hand } \\
\text { washing and use of hand sanitizers }\end{array}$ & 81 & 0.7858 & 75 & 0.3479 & 80 & 1.0000 & 80 & 1.0000 & 80 \\
\hline $\begin{array}{l}\text { A culture of hand washing and/or sanitiza- } \\
\text { tion is promoted at the facility }\end{array}$ & 82 & 0.4182 & 75 & 0.4593 & 80 & 0.8896 & 77 & 0.6720 & 79 \\
\hline $\begin{array}{l}\text { Droplets and contact precautions are } \\
\text { recommended for febrile and coughing } \\
\text { patients }\end{array}$ & 76 & 0.6056 & 76 & 0.7144 & 79 & 0.8914 & 83 & 0.2862 & 78 \\
\hline $\begin{array}{l}\text { Social distancing is promoted in congregate } \\
\text { settings where clients gather }\end{array}$ & 79 & 0.6041 & 72 & 0.371 & 89 & 0.1016 & 73 & 0.4148 & 77 \\
\hline $\begin{array}{l}\text { Good respiratory (e.g. face mask) hygiene is } \\
\text { promoted and communicated }\end{array}$ & 78 & 0.7964 & 71 & 0.2842 & 86 & 0.2215 & 76 & 0.8370 & 77 \\
\hline $\begin{array}{l}\text { One- meter distance between beds is } \\
\text { ensured regardless of whether patients are } \\
\text { suspected of having COVID-19 }\end{array}$ & 70 & 0.4701 & 78 & 0.3865 & 77 & 0.6094 & 72 & 0.8453 & 73 \\
\hline $\begin{array}{l}\text { Patients, and visitors are aware of respira- } \\
\text { tory and hand hygiene and prevention of } \\
\text { healthcare-associated infections }\end{array}$ & 69 & 0.4748 & 72 & 1.000 & 86 & 0.0742 & 71 & 0.8470 & 72 \\
\hline $\begin{array}{l}\text { HCW are applying standard precautions for } \\
\text { all patients }\end{array}$ & 67 & 0.3468 & 73 & 0.7362 & 77 & 0.4528 & 73 & 0.7007 & 71 \\
\hline $\begin{array}{l}\text { Surfaces (e.g. Desks and workstations, } \\
\text { doorknobs, telephones keyboards and } \\
\text { working objects) are regularly wiped with } \\
\text { disinfectant }\end{array}$ & 74 & 0.2358 & 51 & $0.0038^{*}$ & 83 & 0.0838 & 68 & 0.8513 & 69 \\
\hline $\begin{array}{l}\text { Workers who come in direct contact with } \\
\text { clients have been provided with personal } \\
\text { protective equipment }\end{array}$ & 71 & 0.4836 & 66 & 0.7446 & 71 & 0.7151 & 63 & 0.3558 & 68 \\
\hline $\begin{array}{l}\text { Hospital has written COVID-19 prepared- } \\
\text { ness plans and accessible to all staff }\end{array}$ & 63 & 0.2527 & 69 & 0.8701 & 80 & 0.1427 & 72 & 0.4533 & 68 \\
\hline $\begin{array}{l}\text { A person has been assigned responsibility } \\
\text { for communications with staff, regarding } \\
\text { the status and impact of COVID-19 }\end{array}$ & 58 & 0.0726 & 68 & 0.7472 & 77 & 0.1866 & 74 & 0.1375 & 66 \\
\hline
\end{tabular}


Table 7 (continued)

\begin{tabular}{|c|c|c|c|c|c|c|c|c|c|}
\hline & $\begin{array}{l}\text { Central } \\
(n=171) \\
(\%)\end{array}$ & $P$ value & $\begin{array}{l}\text { West Nile } \\
(n=69) \\
(\%)\end{array}$ & $P$ value & $\begin{array}{l}\text { South } \\
\text { Western } \\
(\mathrm{n}=35)(\%)\end{array}$ & $P$ value & $\begin{array}{l}\text { Northern } \\
(\mathrm{n}=95) \\
(\%)\end{array}$ & $P$ value & $\begin{array}{l}\text { Total } \\
(\mathrm{n}=370) \\
(\%)\end{array}$ \\
\hline $\begin{array}{l}\text { Risk of COVID in travel has been assessed. } \\
\text { Non essential travel has been avoided }\end{array}$ & 63 & 0.4966 & 66 & 1.0000 & 86 & $0.0157^{*}$ & 63 & 0.5839 & 66 \\
\hline $\begin{array}{l}\text { Shifts have been introduced to avoid large } \\
\text { concentrations of workers in the facilities }\end{array}$ & 61 & 0.2592 & 63 & 0.6307 & 71 & 0.5499 & 74 & 0.1375 & 66 \\
\hline $\begin{array}{l}\text { A person has been assigned responsibility } \\
\text { for communications with health authori- } \\
\text { ties regarding the status and impact of } \\
\text { COVID-19 }\end{array}$ & 58 & 0.1177 & 70 & 0.4221 & 83 & $0.0312^{*}$ & 66 & 0.8553 & 65 \\
\hline $\begin{array}{l}\text { Facility maintains regular communication } \\
\text { with workers and workers' representatives, } \\
\text { including over the internet, or when not } \\
\text { possible, over the phone }\end{array}$ & 65 & 1.0000 & 63 & 0.7499 & 69 & 0.6350 & 64 & 0.8557 & 65 \\
\hline $\begin{array}{l}\text { A person has been assigned responsibility } \\
\text { for communications with patients, and their } \\
\text { families regarding COVID-19 }\end{array}$ & 58 & 0.5081 & 52 & 0.1624 & 74 & 0.1301 & 68 & 0.2094 & 61 \\
\hline $\begin{array}{l}\text { The facility has mapped the COVID risks/ } \\
\text { hazards of all workpoints and covering all } \\
\text { jobs }\end{array}$ & 63 & 0.5064 & 51 & 0.164 & 66 & 0.4882 & 58 & 0.7234 & 60 \\
\hline $\begin{array}{l}\text { Workers are assisted to manage any emerg- } \\
\text { ing psychosocial risks, new forms of work } \\
\text { arrangements, and in the promotion and } \\
\text { maintenance of healthy lifestyles }\end{array}$ & 62 & 0.1892 & 50 & 0.3582 & 54 & 0.8201 & 49 & 0.2221 & 56 \\
\hline $\begin{array}{l}\text { Non-critical staff have been asked to work } \\
\text { from home or to stay at home }\end{array}$ & 49 & 0.3871 & 52 & 0.8787 & 54 & 0.9099 & 58 & 0.3836 & 53 \\
\hline $\begin{array}{l}\text { Staff safety and health has been included } \\
\text { in the contingency plans, including the } \\
\text { modification of staffing }\end{array}$ & 49 & 0.3861 & 38 & 0.2826 & 57 & 0.1739 & 36 & 0.1145 & 45 \\
\hline
\end{tabular}

preparedness plans accessible to all staff (68\%) and a person had been assigned responsibility for communications with staff, regarding the status and impact of COVID-19 (66\%). The risk of COVID-19 in travel had been assessed with non-essential travel avoided (66\%), shifts introduced to avoid large concentrations of workers in the facilities (66\%) and a person had been assigned responsibility for communication with health authorities regarding the status and impact of COVID-19 (65\%). The facility maintained regular communication with workers and their representatives, including over the internet, or when not possible, over the phone (65\%); a person had been assigned responsibility for communications with patients, and their families regarding COVID-19 (61\%). The facility had mapped the COVID risks/hazards of all work points and covering all jobs (60\%).

There were low-level practices on assistance of workers to manage any emerging psychosocial risks, new forms of work arrangements, and in the promotion or maintenance of healthy lifestyles. Non-critical staff had been asked to work from home or to stay at home (53\%) while staff safety and health had been included in the contingency plans, including the modification of staffing (45\%). This information is shown in Fig. 2 below:
HCWs in the South Western region reported significantly higher level practices $(p$ value $=0.0157)$ in avoiding non-essential travel as compared to the other regions. There was also a significant proportion ( $p$ value $=0.0312$ ) of HCWs reporting that a person had been assigned responsibility for communications with health authorities regarding the status and impact of COVID-19 in the South West compared to other regions. HCWs in private health facilities reported relatively high-level practices compared to their counterparts in public facilities (Table 7).

$\mathrm{HCW}$ ratings of their practices varied geographically. At district level, HCWs in Gulu and Kyegegwa rated their practices significantly higher than HCWs in other districts on average. In terms of facility variations HCWs at HCIII rated their overall staffing, communication, risk mapping and monitoring-related practices significantly higher than HCWs at other levels on average. There were no significant variations in HCWs practices at department or cadre level. Marital status was significantly associated with HCWs self-ratings although the pattern of variation was inconsistent across the different facets of practice. There were no 
Table 8 Variations in HCWs practices by socio-demographic and facility factors

\begin{tabular}{|c|c|c|c|c|}
\hline Characteristic & $\begin{array}{l}\text { Overall practice index } \\
(31-124) \text { Mean (SD) }\end{array}$ & $\begin{array}{l}\text { Patient safety index } \\
\text { (7-28) Mean (SD) }\end{array}$ & $\begin{array}{l}\text { Staff safety index } \\
\text { (12-48) Mean (SD) }\end{array}$ & $\begin{array}{l}\text { Communication, risk mapping and } \\
\text { monitoring index (11-44) Mean (SD) }\end{array}$ \\
\hline \multicolumn{5}{|l|}{ District } \\
\hline Adjumani & $82.5(15.3)^{*}$ & $20.6(5.0)^{*}$ & $31.7(6.9)^{*}$ & $30.2(5.8)^{*}$ \\
\hline Gulu & $96.0(12.3)$ & $22.4(4.3)$ & $37.7(5.5)$ & $35.9(4.7)$ \\
\hline Kabarole & $82.4(15.0)$ & $20.7(3.4)$ & $31.7(6.7)$ & $30.1(6.7)$ \\
\hline Kampala & $85.6(13.5)$ & $20.9(3.2)$ & $33.8(6.0)$ & $30.9(5.7)$ \\
\hline Kyegegwa & $91.6(16.8)$ & $22.2(3.7)$ & $36.2(7.4)$ & $33.2(6.8)$ \\
\hline Mubende & $87.5(15.5)$ & $21.1(3.5)$ & $34.6(6.7)$ & $31.7(6.9)$ \\
\hline \multicolumn{5}{|l|}{ Health facility level } \\
\hline Region Referral hospital & $86.8(13.9)^{*}$ & $21.1(3.4)$ & $33.8(6.3)^{*}$ & $31.9(6.0)^{*}$ \\
\hline General hospital & $82.2(14.8)$ & $20.8(4.4)$ & $31.6(6.5)$ & $29.8(6.0)$ \\
\hline HCIV & 83.6(17.8) & $20.6(4.4)$ & $33.4(7.1)$ & $29.6(7.2)$ \\
\hline $\mathrm{HC}$ III & $98.3(15.3)$ & $23.1(5.0)$ & $39.4(6.9)$ & $35.8(5.4)$ \\
\hline $\mathrm{HC} \|$ & $86.3(6.9)$ & $21.0(2.4)$ & $34.6(4.0)$ & $30.8(3.4)$ \\
\hline Clinic & $95.4(10.1)$ & $22.1(2.6)$ & $38.2(5.4)$ & $35.1(4.5)$ \\
\hline \multicolumn{5}{|l|}{ Gender } \\
\hline Male & $86.0(14.9)$ & $20.9(3.9)$ & $33.7(6.8)$ & $31.4(6.2)$ \\
\hline Female & $87.2(15.2)$ & $21.3(3.8)$ & $34.1(6.6)$ & $31.7(6.4)$ \\
\hline \multicolumn{5}{|l|}{ Education } \\
\hline Certificate & $88.8(15.5)$ & $22.0(3.9)$ & $34.8(6.9)$ & $32.0(6.9)$ \\
\hline Diploma & $85.4(15.5)$ & $20.7(4.0)$ & $33.3(6.8)$ & $31.3(6.3)$ \\
\hline Bachelors'degree & $86.7(15.0)$ & $21.0(3.4)$ & $34.1(6.1)$ & $31.6(6.2)$ \\
\hline \multicolumn{5}{|l|}{ Marital status } \\
\hline Single & $89.7(14.9)^{*}$ & $21.9(3.3)^{*}$ & $35.0(6.9)$ & $32.8(6.0)^{*}$ \\
\hline Married & $85.1(14.6)$ & $20.9(3.8)$ & $33.3(6.4)$ & $30.9(6.2)$ \\
\hline Divorced/separated & $86.2(16.4)$ & $18.6(7.0)$ & $34.9(7.5)$ & $32.7(6.4)$ \\
\hline Widowed & $93.5(32.4)$ & $20.3(9.1)$ & $38.5(11.2)$ & $34.8(12.6)$ \\
\hline \multicolumn{5}{|l|}{ Religion } \\
\hline Catholic & $88.8(15.7)$ & $21.6(4.1)$ & $34.8(6.8)$ & $32.5(6.4)$ \\
\hline Protestant & $85.0(14.2)$ & $20.8(3.4)$ & $33.3(6.5)$ & $30.9(5.9)$ \\
\hline Muslim & $86.8(14.9)$ & $20.8(4.0)$ & $34.0(6.5)$ & $32.0(5.9)$ \\
\hline Pentecostal & $86.1(14.9)$ & $21.3(3.5)$ & $33.9(6.8)$ & $30.8(6.5)$ \\
\hline SDA & $79.1(13.7)$ & $19.1(5.3)$ & $30.3(6.9)$ & $29.2(6.3)$ \\
\hline \multicolumn{5}{|l|}{ Cadre } \\
\hline Consultant & $96.9(14.1)$ & $22.4(2.5)$ & $37.4(7.0)$ & $37.0(5.6)$ \\
\hline Medical officer & $85.0(14.6)$ & $20.4(4.6)$ & $33.3(6.4)$ & $31.3(6.2)$ \\
\hline Clinical officer & $83.6(16.0)$ & $20.3(4.6)$ & $33.0(7.1)$ & $30.3(6.9)$ \\
\hline Reg trained nurse & $86.5(13.3)$ & $20.7(3.1)$ & $34.0(5.9)$ & $31.8(5.8)$ \\
\hline Enrolled nurse & $86.4(17.2)$ & $21.5(4.5)$ & $33.7(7.6)$ & $31.1(6.8)$ \\
\hline Pharmacist & $87.0(12.5)$ & $21.3(2.8)$ & $34.2(5.5)$ & $31.5(6.2)$ \\
\hline Radiographer & $78.6(7.9)$ & $20.0(2.1)$ & $30.2(4.1)$ & $28.4(2.9)$ \\
\hline Laboratory technologist & $87.4(12.8)$ & $21.4(3.2)$ & $34.6(5.8)$ & $31.4(5.4)$ \\
\hline Other & $89.3(16.0)$ & $21.9(3.8)$ & $34.6(7.4)$ & $32.8(6.2)$ \\
\hline \multicolumn{5}{|l|}{ Department } \\
\hline Emergency & $87.2(14.7)$ & $19.9(2.4)$ & $33.9(8.4)$ & $33.4(6.0)$ \\
\hline Outpatient & $87.7(14.3)$ & $21.4(4.1)$ & $34.6(6.2)$ & $31.8(5.8)$ \\
\hline Inpatient & $84.5(16.1)$ & $20.9(3.7)$ & $32.7(6.9)$ & $30.8(6.9)$ \\
\hline Investigative dept & $89.1(15.0)$ & $21.5(3.4)$ & $35.3(6.0)$ & $32.3(6.6)$ \\
\hline Other & $87.9(14.7)$ & $21.3(3.7)$ & $34.6(7.0)$ & $32.1(6.0)$ \\
\hline
\end{tabular}

\footnotetext{
*Statistically significant at $p<0.05$
} 
0\% $10 \%$ 20\% 30\% 40\% 50\% 60\% 70\% 80\% 90\% 100\%

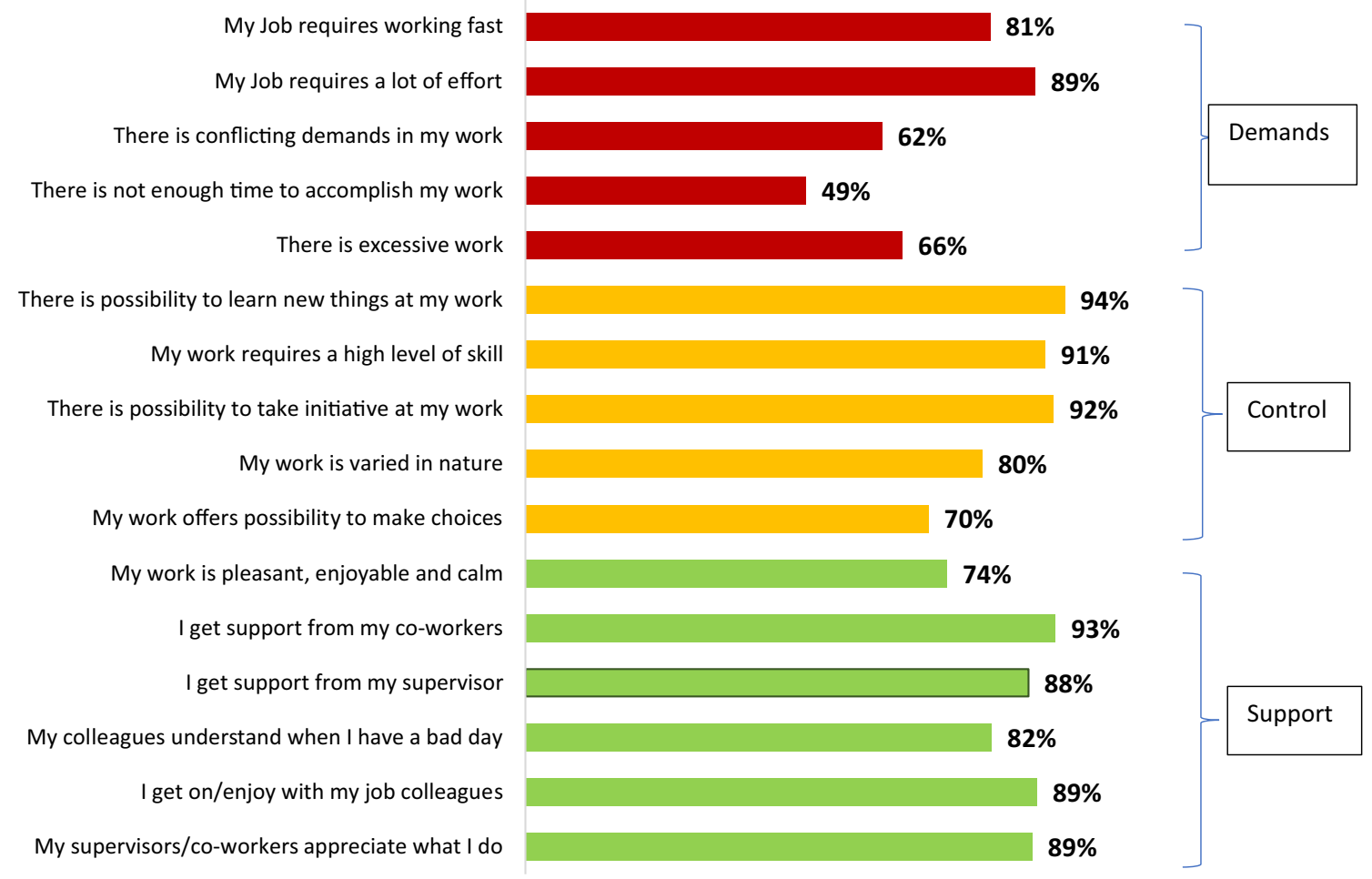

Fig. $3 \mathrm{HCW}$ perceptions on their work environment in relation to COVID-19

variations in $\mathrm{HCW}$ practices by gender, religion and education (Table 8).

\section{Work environment}

HCWs reported increased demands in their work environment in the COVID-19 pandemic era. $81 \%$ indicated that their job requires them to work fast with a lot of effort (89\%), presents conflicting demands (62\%), excessive work (66\%) and lack of adequate time to accomplish work (49\%). However, they also reported increased control in the work environment indicated by a high proportion of HCWs reporting the need to learn new things at work (94\%), high level of skill (91\%), the need to take initiative at work (92\%), variation in the nature of work $(80 \%)$ and possibility of making choices at work (70\%). Inspite of their changing work environment, HCWs reported that they get adequate support in their work. $74 \%$ indicated that their work is enjoyable, pleasant and calm, with support from co-workers (93\%) and supervisors $(88 \%)$ as well as appreciation from supervisor (89\%). The information is shown in Fig. 3.

There was no significant variation in HCW perceptions of their work environment across all regions. There was, however, a significantly lower proportion ( $p$ value $=0.0387)$ of HCWs in West Nile reporting that the job requires them to work fast compared to the other regions. A significantly higher proportion ( $p$ value $=0.0257$ ) of HCWs in the South Western region reported that the job requires them to work fast compared to the other regions. There was no significant variation in the perception of work environment among HCWs across public and private health facilities, gender or education level.

Qualitative findings on $\mathrm{HCW}$ preparedness and frontline practices gave a somewhat different picture in terms of workloads and work environment. While $\mathrm{HCW}$ at referral health facilities reported increased workloads, those at lower level facilities reported reduced patient numbers to attend to in the pandemic era. Some of the explanatory factors for low workloads include COVID-19 movement restrictions, the health system's referral pathway, decongesting high-volume facilities through task shifting or innovative community-based mechanisms and community reluctance to utilize health services-even for suspected COVID-19 cases, due to fear of related stigma and/or isolation:

The stigma attached to respiratory illnesses would consider anyone suffering from respiratory illness to be suffering from COVID so it makes people to fear 
seeking medical attention... these days people who are coughing first struggle with their cough from home before coming here (HCW, In-Settlement Facility 3, Region 1)

Ever since March when the President said "no movement", we have much fewer patients... we nolonger do community dialogues, public health talks and sensitizations all because of COVID. To try and adapt we are using community-based surveillance for case detection and management through ICCM programs like malaria so that people who are badly off can be managed at that level which reduces the turnover at the facility (HCW 5, Region 2)

Health care workers, particularly those at in-settlement health facilities, confirmed being prepared to manage COVID-19 cases:

Our involvement begins from the settlement level to the district level because even as a facility we have a rapid response team. Some members of our facility got training to respond to any case (HCW, In-Settlement Health Facility 1, Region 3)

We are always prepared for epidemics so our level of preparation is somewhere. We have the facilities like the treatment unit, isolation unit within, training of the team and mobilisation is easier and ofcourse we ensure adherence to the SOPs by all staff (HCW, In-Settlement Health Facility 3, Region 1)

This study found one of the biggest challenges to $\mathrm{HCW}$ capacity to mostly be infrastructure and supply-related. Although a number of HCWs at public facilities reported not receiving any or adequate training or capacity building sessions on COVID-19 care, they reported "winging it" or improvising in terms of practice. However, all of them reported struggling to deliver quality healthcare with limited infrastructural adjustments and/or supplies:

I am equipped with information but for utilities like PPEs I am not well equipped (HCW 6, Public Health Facility, Region 4)

I don't think there is a country that has everything, but supplies are a big problem. I personally move with gloves in my bag because we don't have any in the health centre. Last month we only had two boxes of gloves as the whole health centre... 50 pairs in each, that is 100 pairs of gloves... how are we meant to work with these gloves for 60 days? (HCW 7, Public Health Facility, Region 3)

This situation has come with the demand for more human resource and space... also inadequate logistics because stockouts are the order of the day. That includes gloves, handwashing facilities, face- masks and others (HCW, Public Health Facility, Region 4)

Equipment is rare as you can be equipped today and it all runs out the following day because most of utilities for COVID-19 are consumables and disposables so we use them on a daily basis. Support in terms of PPEs is supposed to be a continuous exercise but we don't always have so I don't feel I am adequately equipped to manage (HCW, Public Health Facility, Region 2)

\section{Discussion and conclusions}

This study assessed HCW perceptions about their knowledge and awareness of COVID-19. We found knowledge to be generally low in some areas. Specifically, knowledge regarding symptoms, criteria for admission, treatment options, protection and safety promotion was rated low by a significant number of HCWs. This could be attributed to the study timing where data was collected at the beginning stages of the pandemic with only few COVID-19 cases confirmed in the study setting at the time. The limited knowledge on COVID-19 among HCWs can also partly be explained by a general lack of patients, training and ready guidelines on how to handle a new pandemic. This challenge was not only reported by this study's participants but also several other studies across the world $[38,56,57]$ which confirm a paucity of information and progressive lessons in COVID-19 detection, prevention and management. Clinical guidelines and other related directives began to take shape after pandemic onset and research conducted in early phases was bound to find a general gap in knowledge and practice skills. This gap was exacerbated by the initial comparatively low transmission rates and almost no confirmed COVID-19 cases at most health facilities for an extended period of time. Uganda managed to hold off pandemic mortality for some time-its first COVID-19 case was confirmed on 21st March 2020 and first death registered four months later on 23rd July 2020. In addition, Uganda's health system design and national response to COVID19 required prompt referral to higher-level facilities as opposed to managing cases at all levels [58].

Geographical, regional and district variations in HCW knowledge, attitude and practices were observed, with the South-western (Kyegegwa) and Northern region (Gulu) scoring highest. Several factors could account for these differences. First, Kyegegwa is a direct refugeehosting district with Kyaka II refugee settlement and has a resident implementing partner (IP) exclusively handling refugee health matters within the settlement, although it also serves the surrounding host communities. 
Humanitarian health partners across all settlements actively trained and supported COVID-19 management in their respective units $[28,59]$ partly because they were not constrained or directly under government but supporting the national refugee response. Moreover, the South Western and Northern region had an epidemic management history with response preparedness planning and training following the 2018-2021 Ebola outbreak. This previous experience in managing epidemics also explains the reported higher knowledge levels.

The dynamism and complexity of Uganda's health system design has been highlighted in previous studies [54]. System strengthening led by development and implementing partners in refugee-hosting areas could partly explain why some lower-level HCIIIs reported high level knowledge compared to HCIVs or district hospitals. This is because most in-settlement health facilities are at HCIII level, which was not initially prioritized for full scale COVID-19 training and equipping in the government's phased approach to system strengthening. This would also be a plausible explanation for the underlying KAP variations by health facility ownership (i.e. public vs. private, including profit and not-for-profit private facilities) and community care-seeking behaviour which tends to prefer private over public health facilities, especially for emergencies [60-63]. Gulu as the regional referral lead, where West Nile [Adjumani district] health facilities also referred COVID-19 cases, would have higher knowledge levels and stronger system capacity. Moreover, Gulu has been at the forefront and has history of managing epidemics such as Ebola $[64,65]$ so the infrastructure and experience is in place. A number of studies have indeed supported this notion of system preparedness and resilience following an epidemic [66-68]. We recommend that, due to the evolving nature and trajectory of COVID-19, stronger communities of practice are supported for cross-learning and good practices adopted from more experienced health facilities with flexibility for amendment as new evidence unfolds.

Regional variations on knowledge e.g. on infodemics, which show HCWs in the central region to have higher knowledge than their counterparts, could be due to better information access on COVID-19. Kampala, also the capital city and central business area, was and remains epicenter of the national COVID-19 response. Initially access to information was mostly available via radio, television and print media mostly accessible in urban settings [69]. We recommend further engagement of all HCWs and ongoing information sharing, including through their professional and regulatory bodies.

In all aspects of knowledge, HCWs with atleast a bachelors' degree education exhibited higher knowledge than peers with a diploma or certificate level education.
There is nothing surprising there as the evidence shows direct linkages between HCW education level, regulation, supervision, competence to understand or perform deliver services and improved clinical outcomes in healthcare [70, 71]. However, training and competence variations also highlight the need for comprehensive, systematic, tailored and refresher training for all HCWs with clear outcomes-both for learning and service delivery at the point of care. This is especially needed in resourcelimited settings; in light of limited health workforce and fragile health systems which also require task shifting, ongoing supervision and supportive mechanisms $[48,52]$. The knowledge, skill, and experience of HCWs remain critical inputs for system capacity and resilience [42] during a pandemic and its aftermath. In light of the low human resource capacity, need for task shifting and ongoing capacity building interventions, we recommend a follow-on study that assesses post-training and in-service knowledge and skills of different cadres of health providers 18 or more months into the pandemic, possibly following up the same cohort.

Capacity building methods for healthworkers have a bearing on knowledge retention and application [72, 73]. This study's findings show that the majority of HCWs did not have first-hand experience in managing COVID-19 cases, although some had undergone simulation training in preparation and nearly all HCWs could apply basic clinical knowledge to triage, screen, isolate and refer patients. The evidence shows on-site mentorship and support at the point of care, managing actual cases, to be more beneficial and impactful if certain conditions are met [74-76]. This is for not only service delivery outcomes but also knowledge retention and translation or application among HCWs [75, 76]. HCW and facility practices to effectively manage COVID-19 are constrained by individual factors (e.g. education level, residence, location of work station, hygiene promotion or social distance management) and facility-related factors (e.g. poor information/communication, lack of safety plans, risk monitoring or work environmental threats). The need for infrastructural preparedness, responsive and resilient health systems cannot be overemphasized $[29,68]$. We recommend practical, bespoke and urgent strengthening of system capacity at all levels, especially in light of surging community transmission, a limited health workforce and congested higher-level facilities. This will partly require optimally harnessing the benefits of taskshifting in addition to strengthening cross-site mentorship, learning, coordination and the referral pathway. Robust processes will entail more on-site learning, leveraging technology and the use of data in decisionmaking.

In light of Uganda's fragile health system and limited capacity at most health facilities, there is need to 
empower communities and patients to prevent and selfmanage certain conditions, while emphasising health literacy and telemedicine. Strengthening community-based surveillance and ensuring functional health systems for disease prevention and management is critical in the era of COVID-19, especially for resource-limited settings. There is need to equip community members, leaders, village health teams (VHTs) and lower- level facilities with capacity to respond effectively. In October 2020, and against the backdrop of surging community transmissions, Uganda launched a Community Health Engagement Strategy (CES) with key pillars and a promise to invest the required resources needed for its activation and functionality [77]. Collaboratively engaging local [political, administrative, technical, cultural and religious] leaders to take ownership and emphasise adherence to prevention measures will not only contribute significantly to health system resilience but also community agency, meaningful involvement beyond longstanding tokenism as well as stronger capacity to address the current and future pandemics.

\section{Limitations}

The limitations of this study warrant some acknowledgement. First, this was a rapid assessment of the lived and implementation experiences in refugee settings regarding COVID-19 in specific areas including knowledge, awareness and risk behaviours. As such a cross-sectional study design was most appropriate. With cross sectional findings nonetheless, caution should be practiced in assuming causality. We can only firmly establish associations. The study was conducted in the earlier phase of Uganda's first wave of COVID19. Actual data collection was between September and October 2020 and a lot, including HCW knowledge or health facility capacity, has since changed. More importantly, this study relied on reported knowledge by study participants in lieu of administering knowledge assessments which could have created bias. These challenges notwithstanding, the study seems to be in line with our observations and hypotheses, also providing new insights for the effective management of COVID-19 among refugees in Uganda.

\footnotetext{
Abbreviations

CES: Community Health Engagement Strategy; GDP: Gross Domestic Product; HC: Health Centre; HCWs: Health Care Workers; IDI: Indepth Interview; IPC: Infection Prevention and Control; KAP: Knowledge, Attitudes and Practices; KCCA: Kampala Capital City Authority; MakSPH-HDREC: Makerere University School of Public Health Higher Degrees Research Ethics Committee; MNHC: Maternal, Newborn and child health; MoH: Ministry of Health; NGOs: Non Governmental Organisations; NIPPV: Non Invasive Positive Pressure Ventilation; OPM: Office of the Prime Minister; PPE: Personal Protective Equipment; UNCST: Uganda National Council of Science and Technology.
}

\section{Acknowledgements}

We acknowledge the following who helped with data collection: Francis Abura, Maria Ssematiko, Hilda Namakula, Steven Twinomujuni, Francis Kinuthia, Joshua Aisu and the entire REFLECT field team.

\section{Authors' contributions}

GS, SL and CN contributed to study concept and design. EL and BL participated in study conception and provided technical guidance throughout the study. SL, FO, JK and GS contributed to data analysis. All authors contributed to data collection, interpretation of findings and manuscript writing. All authors read and approved the final manuscript.

\section{Funding}

This research was made possible by a grant (\# 50530 REFLECT in COVID-19) funded by Elrha/R2HC (Research for Health in Humanitarian Crises) supported by UKAID, Welcome and National Institute for Health Research (NIHR). The views expressed in this paper are those of the authors and not the funder.

\section{Availability of data and materials}

All data generated or analysed during this study are included in this published article.

\section{Declarations}

\section{Ethics approval and consent to participate}

The study protocol was approved by Makerere University School of Public Health Research and Ethics Committee (MakSPH-HDREC, \#820). It also obtained clearance from the Uganda National Council of Science and Technology (UNCST), Ministry of Health (MoH), Uganda's Office of the Prime Minister (OPM) and Kampala Capital City Authority (KCCA). We adhered to all standard ethical principles including informed consent, doing no harm to participants, privacy, anonymity and voluntary participation. In addition, the study team adhered to the COVID-19 SOPs which were operationalized to the different regions, study sites and refugee settlements in consultation with local leadership.

\section{Consent for publication}

No individual participant has been identified in this research.

\section{Competing interests}

We have no competing interests.

\section{Author details}

${ }^{1}$ Centre for Health and Social Economic Improvement (CHASE-i) - Department of Social Work and Social Administration (SWSA), Makerere University, Kampala, Uganda. ${ }^{2}$ Department of Health Policy Planning and Management (HPPM), Makerere University School of Public Health (MakSPH), Kampala, Uganda. Infotrak Research Consulting, Nairobi, Kenya. ${ }^{3}$ Public Health Emergency Operations Centre (PHEOC), Ministry of Health, Kampala, Uganda. ${ }^{5}$ Directorate of Health Governance and Regulation, Ministry of Health, Kampala, Uganda. ${ }^{6}$ Agency for Cooperation in Research and Development (ACORD), Nairobi, Kenya. ${ }^{7}$ The Lutheran World Federation (LWF), LWF, Kampala, Uganda. ${ }^{8}$ Department of Public Health - Faculty of Medicine, Gulu University, Gulu, Uganda.

Received: 2 July 2021 Accepted: 7 October 2021

Published online: 03 November 2021

\section{References}

1. Nouri S. Effects of conflict, displacement, and migration on the health of refugee and conflict-stricken populations in the Middle East. Int J Public Health Sci. 2019;8(3):359-72. https://doi.org/10.11591/ijphs.v8i3.18590.

2. IHME COVID-19 health service utilization forecasting team, and Murray CJ. Forecasting the impact of the first wave of the COVID-19 pandemic on hospital demand and deaths for the USA and European Economic Area countries. medRxiv. 2020

3. World Bank Group. An assessment of Uganda's progressive approach to refugee management. World Bank; 2016. 
4. Hattem J. Uganda at breaking point as Bidi Bidi becomes world's largest refugee camp. The Guardian. 2017.

5. UNHCR. Uganda: Refugees and asylum-seekers. UNHCR Representation in Uganda. 2017.

6. Golooba-Mutebi F, Bukenya B, Seruwagi GK. The political economy of refugee-hosting districts in Uganda: A case study of Arua, Moyo and Yumbe districts. 2018.

7. Government of Uganda. Local Governments Act. 1997.

8. World Bank. Informing the refugee policy response in Uganda: results from the Uganda refugee and host communities 2018 household survey. 2018.

9. Ministry of Health (MoH) Uganda Hospitals. 2021. https://www.health.go. ug/hospitals/. Accessed 14 May 2021.

10. Flynn D, Moloney E, Bhattarai N, Scott J, Breckons M, Avery L, Moy N. COVID-19 pandemic in the United Kingdom. Health Policy Technol. 2020;9(4):673-91.

11. Chirico F, Nucera G, Magnavita N. COVID-19: protecting healthcare workers is a priority. Infect Control Hosp Epidemiol. 2020;41(9):1117.

12. Williams $G A$, Maier $C B$, Scarpetti $G$, de Belvis AG, Fattore $G$, Morsella A, Pastorino G, Poscia A, Ricciardi W, Silenzi A. What strategies are countries using to expand health workforce surge capacity during COVID-19 pandemic. TEN. 2020;26(2):51.

13. Arshid MA, Mumtaz M, Nazir R. Unforeseen challenges to global health system, in particular context to COVID-19 pandemic and health care personnel. Arab J Basic Appl Sci. 2020;3:1-9.

14. Zhang Y, Wei L, Li H, Pan Y, Wang J, Li Q, Wu Q, Wei H. The psychological change process of frontline nurses caring for patients with COVID-19 during its outbreak. Issues Ment Health Nurs. 2020;41(6):525-30.

15. Nyashanu M, Pfende F, Ekpenyong M. Exploring the challenges faced by frontline workers in health and social care amid the COVID-19 pandemic: experiences of frontline workers in the English Midlands region, UK. J Interprofessional Care. 2020;34(5):655-61.

16. Asnakew S, Amha H, Kassew T. Mental health adverse effects of COVID-19 pandemic on health care workers in North West Ethiopia: a multicenter cross-sectional study. Neuropsychiatr Dis Treat. 2021;17:1375.

17. Carbajal AB, Boluarte AS, Boluarte AR, Soto CM. Working conditions and emotional impact in healthcare workers during COVID-19 pandemic. J Healthc Qual Res. 2020;35(6):401-402.

18. Firew T, Sano ED, Lee JW, Flores S, Lang K, Salman K, Greene MC, Chang $B$ P. Protecting the front line: a cross-sectional survey analysis of the occupational factors contributing to healthcare workers' infection and psychological distress during the COVID-19 pandemic in the USA. BMJ Open. 2020;10(10):e042752. https://doi.org/10.1136/bmjopen-2020-042752.

19. Erdem $\mathrm{H}$, Lucey DR. Healthcare worker infections and deaths due to COVID-19: a survey from 37 nations and a call for WHO to post national data on their website. Int J Infect Dis. 2021;102:239.

20. Shreffler J, Petrey J, Huecker M. The impact of COVID-19 on healthcare worker wellness: a scoping review. West J Emerg Med. 2020;21 (5):1059. https://doi.org/10.5811/westjem.2020.7.48684.

21. Theorell T. COVID-19 and working conditions in health care. Psychother Psychosom. 2020;16:1

22. Moodley SV, Zungu M, Malotle M, Voyi K, Claassen N, Ramodike J, Thunzi $\mathrm{N}$, Mlangeni N. A health worker knowledge, attitudes and practices survey of SARS-CoV-2 infection prevention and control in South Africa. BMC Infect Dis. 2021;21(1):1-9.

23. SulaimanKanu PB, Bah AJ, Kabba JA, Kamara MS, Williams CE, Kanu JS. Healthcare workers'knowledge, attitude, practice and perceived health facility preparedness regarding COVID-19 in Sierra Leone. J Multidiscip Healthc. 2021;14:67.

24. Fetansa G, Etana B, Tolossa T, Garuma M, Tesfaye Bekuma T, Wakuma B, Etafa W, Fekadu G, Mosisa A. Knowledge, attitude, and practice of health professionals in Ethiopia toward COVID-19 prevention at early phase. SAGE Open Med. 2021. https://doi.org/10.1177/20503121211012220.

25. Roupa Z, Polychronis G, Latzourakis E, Nikitara M, Ghobrial S, Chrysafi A, Noula M. Assessment of knowledge and perceptions of health workers regarding COVID-19: a cross-sectional study from Cyprus. J Community Health. 2021;46(2):251-8.

26. Ejeh FE, Saidu AS, Owoicho S, Maurice NA, Jauro S, Madukaji L, Okon KO Knowledge, attitude, and practice among healthcare workers towards COVID-19 outbreak in Nigeria. Heliyon. 2020;6(11):e05557.
27. Tumwesigye NM, Okethwangu D, Kaakyo M, Biribawa C. Effects of the COVID-19 pandemic on health services and mitigation measures in Uganda. CGD working paper 571. Washington, DC: Center for Global Development. 2021 https://www.cgdev.org/publication/effects-covid19-pandemic-health-services-and-mitigation-measures-uganda-descr iptive.

28. Federica M, Pattnaik A, Jordanwood T, Nakyanzi A, Byakika S. The initial COVID-19 response in Uganda: a case study. Washington, DC: Think Well and Ministry of Health Uganda; 2020.

29. Ajari EE, Ojilong D. Assessment of the preparedness of the Ugandan health care system to tackle more COVID-19 cases. J Glob Health. 2020;10(2):020305. https://doi.org/10.7189/jogh.10.020305.

30. Ndejjo R, Naggayi G, Tibiita R, Mugahi R, Kibira SP. Experiences of persons in COVID-19 institutional quarantine in Uganda: a qualitative study. BMC Public Health. 2021;21(1):1-1.

31. MedScape. In memoriam: Healthcare workers who have died of COVID19. 2020. Available online at: www.medscape.com/viewarticle/927976. Accessed 06 Apr 2021.

32. World Health Organization. Rational use of personal protective equipment (PPE) for coronavirus disease (COVID-19): interim guidance, 19 March 2020 (No. WHO/2019-nCoV/IPC PPE_use/2020.2). World Health Organization.

33. Medscape https://www.medscape.com/viewarticle/927976. Accessed 24 Mar 2021.

34. Tarwirei F, Chirenje ZM, Rusakaniko S. Cancer of the cervix: knowledge, beliefs and screening behaviours of health workers in Mudzi District in Mashonaland East Province, Zimbabwe.

35. Sengwana MJ, Puoane T. Knowledge, beliefs and attitudes of community health workers about hypertension in the Cape Peninsula, South Africa. Curationis. 2004;27(1):65-71.

36. Hughes GD, Puoane T, Bradley H. Ability to manage diabetes-community health workers' knowledge, attitudes and beliefs. J Endocrinol Metab Diabetes S Afr. 2006;11(1):10-4.

37. Burti L, Mosher LR. Attitudes, values and beliefs of mental health workers. Epidemiol Psychiatr Sci. 2003;12(4):227-31.

38. Olum R, Chekwech G, Wekha G, Nassozi DR, Bongomin F. Coronavirus disease-2019: knowledge, attitude, and practices of health care workers at Makerere University Teaching Hospitals, Uganda. Front Public Health. 2020;30(8):181

39. Ministry of Health. Health sector development plan 2015/16-2019/20. Ministry of Health: Kampala; 2015.

40. Kamya C, Abewe C, Waiswa P, Asiimwe G, Namugaya F, Opio C, Ampeire I, Lagony S, Muheki C. Uganda's increasing dependence on development partner's support for immunization: a five year resource tracking study (2012-2016). BMC Public Health. 2021;21(1):1-1.

41. Nampala MP. A critical evaluation of the national health system of Uganda. Biomed J. 2018;2:6.

42. WHO. Everybody's business: strengthening health systems to improve health outcomes-WHO's framework for action. Geneva, Switzerland: World Health Organization. 2007.

43. The Strategic Purchasing Africa Resource Center - SPARC (2021) Strategic health purchasing in Uganda: a summary of progress, challenges, and opportunities. https://sparc.africa/changing-the-conversation/a-theoryof-change-and-practical-steps/policy-briefs/.

44. Zikusooka CM, Kyomuhang R, Orem JN, Tumwine M. Is health care financing in Uganda equitable? Afr Health Sci. 2009;9(2).

45. Yemeke TT, Kiracho EE, Mutebi A, Apolot RR, Ssebagereka A, Evans DR, Ozawa S. Health versus other sectors: multisectoral resource allocation preferences in Mukono district, Uganda. PLoS ONE. 2020;15(7):e0235250.

46. Ministry of Finance Planning and Economic Development (MoFPED). National budget framework paper FY 2019/20-FY 2023/24, 2018. https:// budget.go.ug/sites/default/files/National\%20Budget\%20docs/National\% 20Budget\%20Framework\%20Paper\%20FY\%202019-20.pdf.

47. Koutsoumpa M, Odedo R, Banda A, Meurs M, Hinlopen C, Kramer K, Bemelmans M, Omaswa F, Ojoome V, Kiguli-Malwadde E. Health workforce financing in Uganda: challenges and opportunities. Eur J Public Health. 2020;30(Supplement_5):ckaa165-525.

48. Baine SO, Kasangaki A, Baine EM. Task shifting in health service delivery from a decision and policy makers' perspective: a case of Uganda. Hum Resour Health. 2018;16(1):1-8. 
49. Deller B, Tripathi V, Stender S, Otolorin E, Johnson P, Carr C. Task shifting in maternal and newborn health care: key components from policy to implementation. Int J Gynecol Obstet. 2015;130:S25-31.

50. Kalibala S, Okal J, Zieman B, Jani N, Vu L, Birungi J, Okoboi S, Wangisi J, Nabiryo C, Okullu JL, Etukoit M. Retrospective review of task-shifting community-based programs supporting ARV treatment and retention in Uganda.

51. Sekiziyivu BA, Bancroft E, Rodriguez EM, Sendagala S, Nasirumbi MP, Najjengo MS, Kiragga AN, Musaazi J, Musinguzi J, Sande E, Brad B. Task shifting for initiation and monitoring of antiretroviral therapy for HIVinfected adults in Uganda: the SHARE trial. J Acquir Immune Defic Syndr. 2021;86(3):e71

52. Crowley T, Mayers P. Trends in task shifting in HIV treatment in Africa: effectiveness, challenges and acceptability to the health professions. Afr J Prim Health Care Fam Med. 2015;7(1):1-9.

53. Ministry of Health, Health Systems 20/20, and Makerere University School of Public Health. Uganda health system assessment 2011. Kampala, Uganda and Bethesda, MD: Health Systems 20/20 project, Abt Associates Inc. 2012

54. Kirunga Tashobya C, Ssengooba F, Nabyonga-Orem J, Bataringaya J, Maca J, Marchal B, Musila T, Criel B. A critique of the Uganda district league table using a normative health system performance assessment framework. BMC Health Serv Res. 2018;18(1):1-7.

55. Bloom BS. Taxonomy of educational objectives. Cognitive domain, vol. 1. New York: McKay; 1956. p. 20-4

56. Nguyen LH, Drew DA, Graham MS, Joshi AD, Guo CG, Ma W, Mehta RS, Warner ET, Sikavi DR, Lo CH, Kwon S. Risk of COVID-19 among front-line health-care workers and the general community: a prospective cohort study. Lancet Public Health. 2020;5(9):e475-83.

57. Gooch K. $79 \%$ of nurses say healthcare workers lack enough information on COVID-19 vaccines. American Nurses Association (ANA); 2020. https:// www.beckershospitalreview.com/workforce/79-of-nurses-say-healthcareworkers-lack-enough-information-on-covid-19-vaccines.html.

58. Government of Uganda (GoU). COVID-19 response info hub. https:// covid19.gou.go.ug/timeline.html.

59. Medical Teams International. Fighting coronavirus in Uganda and the U.S.: a tale of two countries. 2020. https://medicalteams.org/news/fightingcoronavirus-in-uganda-and-the-u-s-a-tale-of-two-countries/. Accessed 14 May 2021

60. Pariyo GW, Ekirapa-Kiracho E, Okui O, Rahman MH, Peterson S, Bishai DM, Lucas $\mathrm{H}$, Peters DH. Changes in utilization of health services among poor and rural residents in Uganda: are reforms benefitting the poor? Int J Equity Health. 2009;8(1):1-1.

61. Bustreo F, Harding A, Axelsson H. Can developing countries achieve adequate improvements in child health outcomes without engaging the private sector? Bull World Health Organ. 2003;81(12):886-95.

62. Konde-Lule J, Gitta SN, Lindfors A, Okuonzi S, Onama VO, Forsberg BC. Private and public health care in rural areas of Uganda. BMC Int Health Hum Rights. 2010;24(10):29. https://doi.org/10.1186/1472-698X-10-29. PMID:21106099;PMCID:PMC3003635.

63. Kiwanuka SN, Ekirapa EK, Peterson S, Okui O, Rahman MH, Peters D, Pariyo GW. Access to and utilisation of health services for the poor in Uganda: a systematic review of available evidence. Trans R Soc Trop Med Hyg. 2008;102(11):1067-74. https://doi.org/10.1016/j.trstmh.2008.04.023.
64. Okware SI, Omaswa F, Talisuna A, Amandua J, Amone J, Onek P, Opio A, Wamala J, Lubwama J, Luswa L, Kagwa P. Managing Ebola from rural to urban slum settings: experiences from Uganda. Afr Health Sci. 2015;15(1):312-21.

65. Lamunu M, Lutwama JJ, Kamugisha J, Opio A, Nambooze J, Ndayimirije N, Okware S. Containing a haemorrhagic fever epidemic: the Ebola experience in Uganda (October 2000-January 2001). Int J Infect Dis. 2004;8(1):27-37.

66. Sundararaman T, Muraleedharan VR, Ranjan A. Pandemic resilience and health systems preparedness: lessons from COVID-19 for the twenty-first century. J Soc Econ Dev. 2021;6:1-1.

67. Kruk ME, Myers M, Varpilah ST, Dahn BT. What is a resilient health system? Lessons from Ebola. The Lancet. 2015;385(9980):1910-2.

68. Kruk ME. Emergency preparedness and public health systems: lessons for developing countries. Am J Prev Med. 2008;34(6):529-34. https://doi.org/ 10.1016/j.amepre.2008.02.012.

69. Bukuluki P, Mwenyango H, Katongole SP, Sidhva D, Palattiyil G. The socioeconomic and psychosocial impact of Covid-19 pandemic on urban refugees in Uganda. Soc Sci Humanit Open. 2020;2(1):100045.

70. Dieleman M, Gerretsen B, van der Wilt GJ. Human resource management interventions to improve health workers' performance in low and middle income countries: a realist review. Health Res Policy Syst. 2009;7:7. https:// doi.org/10.1186/1478-4505-7-7.

71. Sutherland K, Leatherman S. Regulation and quality improvement. A review of the evidence. London: The Health Foundation; 2006.

72. Bluestone J, Johnson P, Fullerton J, Carr C, Alderman J, Bon TJ. Effective inservice training techniques, timing, setting and media: evidence from an integrative review of the literature. Baltimore: Jhpiego Corporation; 2012.

73. Leslie HH, Gage A, Nsona H, Hirschhorn LR, Kruk ME. Training and supervision did not meaningfully improve quality of care for pregnant women or sick children in sub-Saharan Africa. Health Aff (Millwood). 2016;35(9):1716-24. https://doi.org/10.1377/hlthaff.2016.0261 (PMID: 27605655).

74. Ajeani J, MangwiAyiasi R, Tetui M, Ekirapa-Kiracho E, Namazzi G, MuhumuzaKananura R, NamusokeKiwanuka S, Beyeza-Kashesya J. A cascade model of mentorship for frontline health workers in rural health facilities in Eastern Uganda: processes, achievements and lessons. Glob Health Action. 2017;10(sup4):1345497. https://doi.org/10.1080/16549716.2017. 1345497.

75. Matovu JK, Wanyenze RK, Mawemuko S, Okui O, Bazeyo W, Serwadda D. Strengthening health workforce capacity through work-based training. BMC Int Health Hum Rights. 2013;13(1):1-3.

76. Kisakye AN, Muhumuza Kananura R, Ekirapa-Kiracho E, Bua J, Akulume M, Namazzi G, Namusoke KS. Effect of support supervision on maternal and newborn health services and practices in Rural Eastern Uganda. Glob Health Action. 2017;10(sup4):1345496.

77. Government of Uganda (2020) National community engagement strategy for COVID-19 response

\section{Publisher's Note}

Springer Nature remains neutral with regard to jurisdictional claims in published maps and institutional affiliations.

Ready to submit your research? Choose BMC and benefit from

- fast, convenient online submission

- thorough peer review by experienced researchers in your field

- rapid publication on acceptance

- support for research data, including large and complex data types

- gold Open Access which fosters wider collaboration and increased citations

- maximum visibility for your research: over $100 \mathrm{M}$ website views per year

At BMC, research is always in progress.

Learn more biomedcentral.com/submissions 